\title{
MODELO MATEMÁTICO DA RESPOSTA IMUNE À INFECÇÃO PELO VÍRUS HIV-1
}

\author{
MARCELO ROSSI
}

Tese (Doutorado) apresentada ao Programa de Pós-Graduação Interunidades em Biotecnologia USP / Instituto Butantan / IPT, para obtenção do Título de Doutor em Biotecnologia. 


\title{
MODELO MATEMÁTICO DA RESPOSTA IMUNE À INFECÇÃO PELO VÍRUS HIV-1
}

\author{
MARCELO ROSSI
}

Tese (Doutorado) apresentada as Programa de Pós-Graduação Interunidades em Biotecnologia USP / Instituto Butantan / IPT, para obtenção do Título de Doutor em Biotecnologia.

Área de Concentração: Biotecnologia

Orientador: Luis Fernandez Lopez 
DADOS DE CATALOGAÇÃO NA PUBLICAÇÃO (CIP)

Serviço de Biblioteca e Informação Biomédica do

Instituto de Ciências Biomédicas da Universidade de São Paulo

(C) reprodução total

Rossi, Marcelo.

Modelo matemático da resposta imune à infecção pelo vírus HIV-1 I Marcelo Rossi. -- São Paulo, 2008.

Orientador: Prof. Dr. Luis Fernandez Lopes.

Tese (Doutorado) - Universidade de São Paulo. Instituto de Ciências Biomédicas. Programa de Pós-Graduação Interunidades em Biotecnologia EP/IPT/ICB/Butantan. Área de concentração:

Biotecnologia. Linha de pesquisa: Epidemiologia.

Versão do título para o inglês: Immune response mathematical model to HIV virus infection.

Descritores: 1. Modelagem matemática 2. Sistema imune 3. Infecção por HIV 4. Equação diferencial com retardamento 5. Epidemiologia 6. I. Lopes, Lucia Fernandez II. Universidade de São Paulo. Instituto de Ciências Biomédicas. Programa de PósGraduação em Biotecnologia. III. Título. 


\section{UNIVERSIDADE DE SÃO PAULO \\ Programa de Pós-Graduação Interunidades em Biotecnologia \\ Universidade de São Paulo, Instituto Butantan, Instituto de Pesquisas Tecnológicas}

Candidato(a): $\quad$ Marcelo Rossi.

Título da Tese: $\quad$ Modelo matemático da resposta imune à infecção pelo vírus HIV-1.

Orientador(a): $\quad$ Luis Fernandez Lopes.

A Comissão Julgadora dos trabalhos de Defesa da Tese de Doutorado, em sessão pública realizada a I. considerou

\section{( ) Aprovado(a) （ ) Reprovado(a)}

Examinador(a): Assinatura:

Nome:

Instituição:

Examinador(a): $\quad$ Assinatura:

Nome:

Instituição:

Examinador(a): $\quad$ Assinatura:

Nome:

Instituição:

Examinador(a): $\quad$ Assinatura:

Nome:

Instituição:

Presidente: Assinatura:

Nome:

Instituição: 


\section{AGRADECIMENTOS}

Difícil colocarmos em palavras todas as lembranças, os julgamentos, momentos felizes (e outros nem tanto), e agradecer a todos nesta folha de papel. Mas alguns tiveram sua notoriedade e importância e, portanto, devem ser mencionados!

Primeiramente, agradeço ao meu orientador e amigo, Luis Fernandez Lopez, pela orientação, ajuda e incentivo para a construção e conclusão do trabalho;

Agradeço aos demais professores da DIM (Disciplina de Informática Médica): Eduardo Massad, Francisco Coutinho e Marcelo Burattini, pelo auxilio, paciência, pela atenção, amizade e que a alegria de confiar no meu trabalho;

Nestes quatro anos de Doutorado, alguns colegas de trabalho que se tornaram amigos, como a Lêuda, o Hélio, a Márcia. A eles, meu muito obrigado de coração!

Aos meus demais colegas: Harki, Paulo César, Edna, Danilo, Silvia, Clarice, Euro, ao pessoal do Laboratório de Retrovirologia (UNIFESP), sempre prontos a me ajudar nas dúvidas de Imunologia Viral;

Aos funcionários Vilma, Sandra, Iracene e Jorge: meu muito obrigado pela atenção e ajuda nos momentos difíceis.

Meu muito obrigado também vai para a Marlyi, que contribuiu muito pelo término da tese, tanto pelo incentivo ou pelas boas risadas quanto por comentários certeiros e construtivos.

A todos que de uma maneira ou outra, contribuíram para este trabalho, meu sincero agradecimento. 
“... Ora, a fé é o firme fundamento das coisas que se esperam, e a prova das coisas que não se vêem..."

$\mathrm{Hb} 11: 1$ 


\section{Resumo}

Rossi, M. Modelo matemático da Resposta Imune à infecção pelo vírus HIV-1 [Thesis]. São Paulo; Instituto de Ciências Biomédicas da Universidade de São Paulo; 2008.

Hoje em dia, a AIDS tem se tornado uma epidemia que tem movimentado vários tipos de atitudes, sejam aquelas relativas às pessoas, instituições e grupos específicos na prevenção do contágio e na ação de medicamentos. O uso de medicamentos tem conduzido o paciente a quadros de qualidade de vida cada vez melhores. Todavia, esquemas de tratamentos com drogas utilizados hoje acabam derivando um quadro de aumento na quantidade de variantes genéticas virais bem como de mutações relacionadas com as resistências à essas substâncias, impelindo a necessidade de pesquisa de novas substâncias com vantagens sobre as atuais. O desconhecimento sobre o funcionamento e ação do Sistema Imunológico frente à infecção e instalação do HIV-1 vem diminuindo a cada dia com os desafios de um ramo de pesquisa que tem, como objetivo, melhor compreender os mecanismos celulares que levam à AIDS. No presente trabalho, um modelo matemático foi criado com as principais populações envolvidas na infecção Macrófagos, Células dendríticas e os linfócitos $\mathrm{TCD}^{+}$e $\mathrm{TCD}^{+}$ou CTL - e, em cujas simulações, demonstraram que a cinética de infecção depende fortemente do conjunto de macrófagos ativos infectados (que são 43\% da sua população total) e que 93\% das células dendríticas contém partículas virais atreladas aos seus receptores de membrana. A carga viral que o indivíduo soropositivo sem medicação detém acaba esgotando a proliferação dos linfócitos $\mathrm{TCD}^{+}$possivelmente por drenagem constante, correlacionada ao processo de apresentação de antígeno, ou à constante infecção pela presença do HIV-1 ou mesmo por co-adaptação do vírus ao Sistema Imunológico, cujo resultado é um decaimento dos $\mathrm{TCD}^{+}$para níveis abaixo dos 350 cell $(\mu \mathrm{l})^{-1}$ em 8 anos. Conclui-se, também, que a população de linfócitos $\mathrm{TCD}^{+}$(CTL) não é capaz de suprimir totalmente o avanço da infecção viral, revelando o escape viral como um mecanismo alternativo de sobrevivência do HIV-1. 


\begin{abstract}
Rossi, M. Modelo matemático da Resposta Imune à infecção pelo vírus HIV-1 [Thesis]. São Paulo; Instituto de Ciências Biomédicas da Universidade de São Paulo; 2008.
\end{abstract}

\begin{abstract}
AIDS has become an epidemic that has moved several types of attitudes, are those relating to persons, institutions and specific groups in the prevention of infection and the action of drugs. The drugs use has led the patient to higher life quality. However, drug treatments schemes used today end up leading a framework of increase in the viral genetic variants amount and mutations related to these chemicals resistance to, pushing the need to search for new substances with advantages over the present. The ignorance about the Immune System operation and action against the infection and installation of HIV-1 is decreasing every day with the challenges of a branch of research that has, as objective, better knowledge of the cellular mechanisms that lead to AIDS. In this paper, a mathematical model was created with the main cellular set involved in the infection Macrophages, dendritic cells and $\mathrm{CD}^{+}$and $\mathrm{CD}^{+} \mathrm{T}$ cell or CTL - and, in whose simulations have shown that the infection kinetics depends, heavily, on the number of infected macrophages subset (which are $43 \%$ of this total population), and that $93 \%$ of dendritic cells containing viral particles assigned to its receptors of membrane. The individual seropositive viral load without medication has just depleted the proliferation of $\mathrm{CD}^{+} \mathrm{T}$ cell count possibly by constant drainage, correlated to the antigen presentation process, or the infection constant presence by HIV-1 or even by co-adaptation of the virus to the Immune System, whose result is a $\mathrm{CD}^{+} \mathrm{T}$ cells decay to levels below 350 cell $(\mu 1)^{-1}$ on 8 years. It is also that the population of TCD $8^{+}$lymphocytes (CTL) is not able to completely suppress the progress of viral infection, revealing the viral escape as an alternative mechanism to HIV-1 survival.
\end{abstract}




\section{LISTA DE ILUSTRAÇÕES}

Figura 1: Esquema funcional das etapas do processo de reconhecimento, ativação e proliferação do sistema imunológico nas fases inata $\mathrm{e}$ adquirida

Figura 2: (a) Foto resultante de microscopia eletrônica de célula Macrófago "consumindo" dois linfócitos; (b) Foto mostrando um exemplo de célula dendrítica, denominada Célula de Langerhans..

Figura 3: Foto de um Linfócito mostrando várias ramificações em sua membrana celular

Figura 4: Esquema funcional da ativação dos linfócitos T. (1) Macrófagos ativos fagocitam os corpúsculos estranhos ao nosso corpo (antígenos); (2) Apresentação dos fragmentos destes corpúsculos aos linfócitos $\mathrm{T}$ auxiliares ( $\mathrm{TCD}^{+}{ }^{+}$; (3) Ativação da resposta imune adaptativa, com os linfócitos TCD4 sinalizando (citocinas) as populações de células Natural Killers, Citotóxicas e Linfócitos B; (4) Linfócitos Citotóxicos (TCD8 ${ }^{+}$) seguem destruindo as células infectadas pelos antígenos ...........................

$\begin{array}{ll}\text { Figura 5: } & \text { Órgãos linfáticos do corpo humano ....................................................... } \\ \text { Figura 6: } & \text { Macrófago no momento de captura e engolfamento de bactérias em seus }\end{array}$ vacúolos

Figura 7:

Esquema representativo da implicação das variantes virais no processo de infecção dos linfócitos, células dendríticas e linfonodos

Figura 8: Esquema que mostra o processo de acoplamento, ancoragem e invasão do vírus HIV no linfócito TCD4 ${ }^{+}$

Figura 9: Fotos em microscopia de varredura, que foram coloridas posteriormente, mostrando a aproximação e conecção dos vírus HIV à membrana celular dos linfócitos TCD4+, mostrando a relação de tamanho, a quantidade e o processo de brotamento

Figura 10: Fluxograma esquemático do funcionamento do Sistema Imune quando da presença do vírus HIV

Figura 11: Perfis de variação das concentrações de (a) macrófagos ativos e ativos infectados; (b) Células dendríticas imaturas e maduras (acopladas com vírus); (c) Linfócitos ativos e produtivamente infectados; (d) linfócitos TCD4+ produtivamente infectados; (e) linfócitos TCD4+ cronicamente infectados;(f) linfócitos CTL e $\quad$ (g) carga Implicação do uso de diferentes valores para o delay de infecção da

Figura 12: Implicação do uso de diferentes valores para o delay de infecção da
cinética dos compartimentos celulares no decorrer da infecção pelo vírus HIV-1

Gráficos relativos aos perfis de variação de macrófagos, linfócitos TCD4+ ativos e produtivamente infectados e linfócitos CTL, bem como da carga viral em três diferentes valores de atrasos (delay) no período inicial da infecção 


\section{LISTA DE TABELAS}

Tabela 1: Valores e descrição dos parâmetros cinéticos do Modelo ......................... 39

Quadro 1: Apresentação dos compartimentos adotados para o modelo ..................... 36

Quadro 2: Descrição e referencia das variáveis de estado existentes ....................... 41 


\section{SUMÁRIO}

1. Revisão da literatura 08

$\begin{array}{ll}\text { 1.1 Aids no Brasil } & 08\end{array}$

$\begin{array}{ll}1.2 \text { Medicamentos utilizados } & 10\end{array}$

$\begin{array}{ll}\text { 1.3 Funcionamento do Sistema imunológico } & 10\end{array}$

1.3.1 Resposta imune inata 13

$\begin{array}{ll}\text { 1.3.2 Resposta imune adaptativa } & 14\end{array}$

Citocinas 18

1.3.3 Sistema Imune: Ação na presença do vírus HIV-1 19

I.1 Macrófagos 21

I.2 Células dendríticas 23

I.3 Linfócitos TCD4+ 26

I.4 Linfócitos TCD4+ "de memória" 27

I.5 Linfócitos TCD8+ ou CTL 28

I.6 Vírus HIV-1 28

1.3.4 Receptores quimioscinas e o tropismo X4 e R5 30

1.4 Os modelos matemáticos $\quad 32$

1.5 Objetivos principais $\quad 35$

2. Materiais e Métodos 36

2.1 Descrição das equações do Modelo Matemático 36

2.2 Descrição do conjunto de equações 38

2.3 Simulação do modelo $\quad 45$

3. Resultados e discussão 48

4. Conclusões $\quad 60$

Referência Bibliográfica $\quad 62$

Apêndice A $\quad 68$

$\begin{array}{ll}\text { Apêndice B } & 72\end{array}$

$\begin{array}{ll}\text { Anexo I } & 73\end{array}$ 


\section{1. $\underline{\text { Revisão da literatura }}$}

\subsection{AIDS no Brasil}

No Brasil, em 2004 já haviam sido contabilizados 172 mil casos de óbitos por AIDS e até o mês de junho de 2005 foram notificados cerca de 371 mil casos. Desse total, uma fração de $80 \%$ está concentrada nas regiões Sul e Sudeste, sendo esta última a que mostra uma relativa estabilização da epidemia desde 1998. Uma pesquisa posterior, de abrangência nacional, estimou que em 2004 houvesse cerca de 593 mil brasileiros portadores de HIV e AIDS (0,61 \% da população) entre 15 e 54 anos sendo, aproximadamente, a terça parte composta de mulheres (cerca de 204 mil). Observa-se uma estabilização dos óbitos em torno de 5,8 óbitos para cada 100 mil habitantes a partir de 2005, tendência mais evidente na região Sudeste e mais elevada entre pacientes do sexo masculino.

Em 2004 estimou-se que, através de pesquisas de âmbito nacional, havia em torno de 593 mil pessoas, entre 15 a 49 anos de idade, convivendo com o vírus HIV-1 e com Aids, destacando que cerca de 204 mil (34,4 \%) são mulheres e 389 mil (65,6 \%), homens. Tais pesquisas também demonstraram que a relação sexual sem o uso de preservativo (em torno de 91\% dos entrevistados de 15 a 49 anos) foi a forma mais evidente de transmissão e infecção, expondo uma grande contradição, onde $94 \%$ dos mesmos entrevistados citaram, em outro ponto da pesquisa, o uso do preservativo como forma de prevenção da infecção. Tal esclarecimento associado à prevenção é mais forte nas regiões Sul e Sudeste devido o maior nível de escolaridade da população envolvida na pesquisa ${ }^{1}$. Até o final de Junho de 2007, o Sistema de Vigilância Epidemiológica notificou, no Estado de São Paulo, 115.302 casos novos de Aids, onde 70,36 \% são do sexo masculino e $29,64 \%$ pertence ao sexo feminino.

Após a adoção da terapia anti-retroviral potente (Highly Active Antiretroviral Therapy - HAART), observou-se uma queda no número de óbitos relacionados à Aids, alcançando um índice de 6,3 óbitos por 100 mil habitantes no ano de 2000, sendo que, anteriormente, a taxa era de 9,3 óbitos por 100 mil habitantes com uma taxa incidente de crescimento alcançando o valor de 17 casos de AIDS por 100 mil habitantes no ano de 1998.

Segundo a Organização Mundial de Saúde, os fundos para auxílio no tratamento de Aids variaram de US\$ 1.6 bi em 2001 à US\$ 8.3 bi em 2005, alcançando a estimativa de US\$

\footnotetext{
${ }^{1}$ Aids em números. Disponível em http://www.aids.gov.br . Acesso em 27 de Junho de 2006.
} 
10 bi em 2008. Contudo, segundo o mesmo órgão, apenas uma parte é gasta com o tratamento dos pacientes já que programas de prevenção, apesar de eficazes, conseguem atender, no máximo, 15\% dos pacientes. No Brasil, os gastos do Sistema Único de Saúde (SUS), segundo Portela, Lotrowska (2006), com o tratamento e assistência figura em pouco menos de R\$ 20 milhões em 1998 para cerca de R\$ 27,3 milhões em 2004. Estes autores citam também que a região majoritária foi a região Sudeste com o menor custo médio por internação. Segundo eles, no Brasil o custo médio de internação variou entre R \$550,00 (em 1998) à R \$ 700,00 (2004), sendo os maiores custos registrados nas Regiões Norte e Sul do país. O acesso universal aos anti-retrovirais, fomentado pelo Governo Brasileiro, representa um gasto anual de R \$ 450 milhões, aproximadamente, atingindo cerca de 170 mil pacientes.

Tal política é composta por:

Uma produção nacional de medicamentos não-patenteados;

Negociações de preços com a Indústria Farmacêutica;

Atuação internacional visando uma alteração das legislações vigentes quanto propriedade intelectual e também de acesso a medicamentos.

Como resultado da aplicação destes itens, entre 1997 e 2004 foi observada uma redução de 4,6 vezes no preço médio dos medicamentos antivirais (US\$ 6.200 para US\$ 1.300) (PORTELA, LOTROWSKA; 2006). Porém, o Ministério da Saúde estima que tal queda dê lugar a um aumento expressivo no custo per capita devido à uma queda no uso de medicamentos de primeira linha (produzidos no Brasil e com custo de U\$ 600 por paciente por ano) e aumento no uso de antivirais de segunda linha (importados e protegidos por patentes).

Em suma, há a necessidade de trabalhos e/ou projetos que favoreçam ou auxiliem o uso racional destes recursos na prevenção e no tratamento da Aids no Brasil.

\subsection{Medicamentos utilizados}

O Programa Brasileiro de combate à Aids é uma referencia no mundo todo e o país produz formas genéricas dos anti-retrovirais importados desde 1994, quando o Governo Brasileiro foi acusado de quebra de patente por multinacionais farmacêuticas. Hoje, do 
conjunto de 14 medicamentos que podem ser usados para compor o coquetel anti-Aids e que são distribuídos gratuitamente pelo Ministério da Saúde, 10 são fabricados no Brasil e os demais adquiridos por importação ${ }^{2}$.

No Laboratório FarManguinhos são produzidos 8 medicamentos: Didanosina, Estavudina, Indinavir, Lamivudina, Nevirapina, Zidovudina e o composto Lamivudina + Zidovudina. Na mesma empresa, são produzidos o Efavirenz (Merck) e o Nelfinavir (Roche) o que possibilitou ao Brasil uma redução de $59 \%$ e $40 \%$ no preço dos respectivos medicamentos. Em agosto de 2001, a patente do Nelfinavir foi quebrada e, após meses de discussões, a Roche concordou em reduzir em $40 \%$ o preço do fármaco, gerando uma economia de R $\$ 88,5$ bilhões anuais. Ainda sim, o Nelfinavir continua um dos mais caros do tratamento, correspondendo a $28 \%$ do preço do coquetel. Outras moléculas novas estão em fase de testes e serão produzidas pelo Laboratório futuramente.

\subsection{Funcionamento do Sistema Imunológico}

O sistema imune (ou sistema imunológico) tem a função de produzir uma resposta com a finalidade de defender nosso organismo contra agentes invasores (antígenos) - como vírus, bactérias, fungos, protozoários ou parasitas multicelulares - ou corpos estranhos, possíveis causadores de doenças, podendo levar o hospedeiro a óbito se sua multiplicação ocorrer de forma descontrolada. Portanto, tal sistema - denominado respostas imunes inatas e adaptativas - cria barreiras com o auxílio de determinadas substâncias e células que detectam e, geralmente, eliminam o agente invasor antes que ele cause algum dano ao hospedeiro (Machado et al., 2004) ${ }^{3}$ (Figura 1).

Qualquer resposta imunológica envolve, primeiramente, o reconhecimento do antígeno, que são pequenos fragmentos da célula invasora e, em segundo lugar, a elaboração de uma nova reação dirigida a esse elemento, com a finalidade de eliminá-lo do organismo. Tal reconhecimento se dá através do contato com os anticorpos, que são proteínas que reconhecem porções específicas dos agentes patogênicos levando a uma rápida reação em cadeia no organismo culminando na destruição dos agentes infecciosos. Como os antígenos, de modo geral, não possuem uma composição química característica, sua definição repousa

\footnotetext{
${ }^{2}$ Anti-retroviral contra AIDS. Disponível em http://www.far.fiocruz.br . Acesso em 01 de Agosto de 2006.

${ }^{3}$ Convido o leitor a ler este review sobre os Mecanismos de Respostas Imunes.
} 
inteiramente na relação da capacidade do estímulo de resposta imune, da funcionalidade e o tipo desta resposta, sendo considerada mais geral e não-específica.

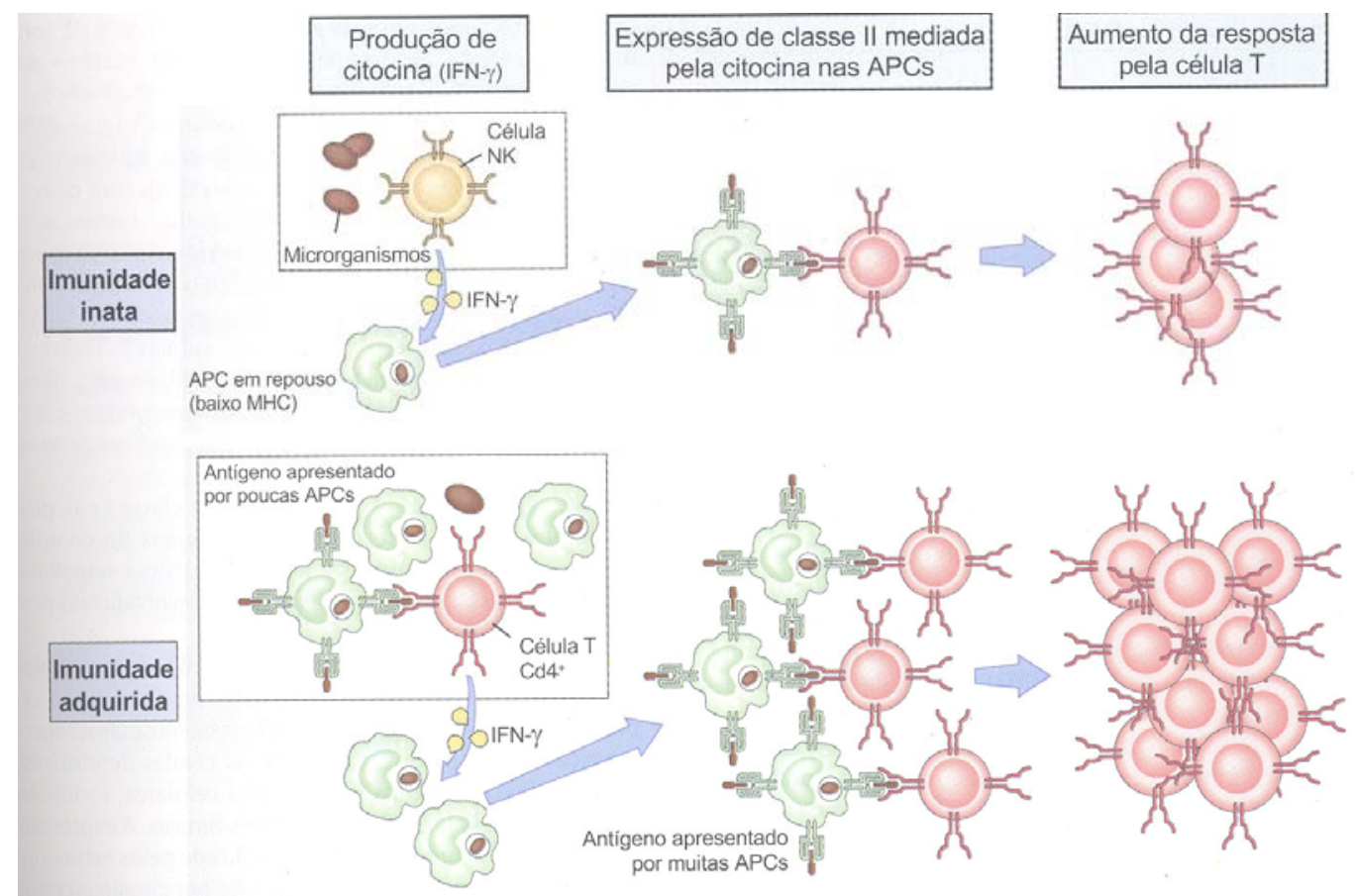

Figura 1 Esquema funcional das etapas do processo de reconhecimento, ativação e proliferação do sistema imunológico nas fases inata e adquirida.

Fonte: ABBAS, LICHTMAN, POBER; 2003.

Os diferentes tipos de resposta imunológica enquadram-se em duas categorias: resposta imune inata (ou não-adaptativa) e resposta imune adaptativa.

\subsubsection{Resposta Imune Inata:}

Denomina-se resposta imune inata o conjunto de reações bioquímicas e celulares nãoespecíficas onde participam células acessórias com capacidade fagocítica, como monócitos, macrófagos e neutrófilos. Estas células reconhecem, fagocitam (“englobam”) e destroem um antígeno de forma não específica (ou seja, não importando o tipo de antígeno), constituindo a primeira linha de defesa humana contra a invasão de corpos estranhos. Porém, tal característica não confere uma imunidade total de longa duração ou protetora ao organismo hospedeiro. 


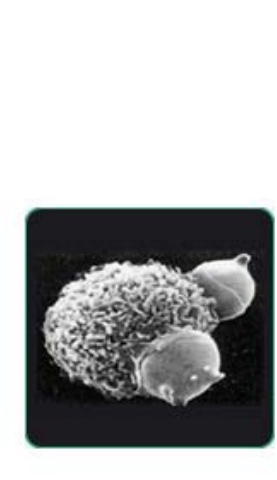

(a)

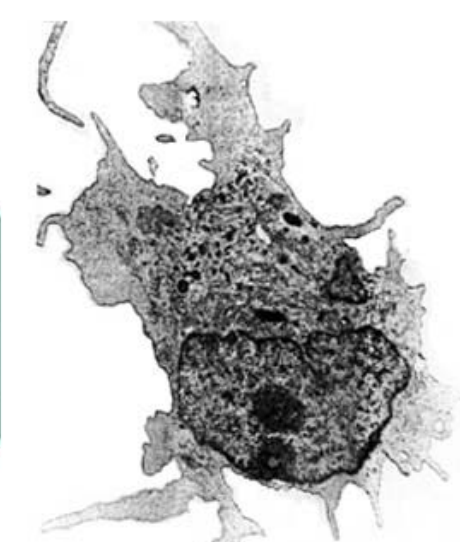

(b)

Figura 2: (a) Foto resultante de microscopia eletrônica de célula macrófago acoplando com duas hemáceas; (b) Foto mostrando um exemplo de célula dendrítica, denominada Célula de Langherans. Fonte: www.zoology.ubc.ca/ berger/B200sample/unit_9_secretion/endocytosis.htm

Estas "barreiras" de reações bioquímicas, presentes em inflamações estimuladas por fatores (ou mediadores) moleculares, são estabelecidas por substâncias especializadas denominadas citocinas, liberadas no sítio de infecção ou de inflamação e apresentadas como "moléculas ativadoras" de outro conjunto celular (linfócitos). Um outro conjunto de reações denominado complementar traz uma cascata bioquímica que auxilia os anticorpos a destruírem ou marcá-los para destruição por outras células. No Apêndice A são encontradas as principais interleucinas, onde estas atuam e principais fontes celulares.

Por sua vez, a barreira celular é exercida por um conjunto de células pertencentes ao grupo dos leucócitos, não ligada a nenhum órgão ou tecido e agindo livremente no organismo. Os leucócitos inatos incluem, entre outros: eosinófilos, basófilos, células Natural Killer e fagócitos (macrófagos, neutrófilos e células dendríticas) (Figura 2). Estes mediadores celulares são também importantes na ativação da resposta imune adaptativa através do processo de apresentação de antígenos. 


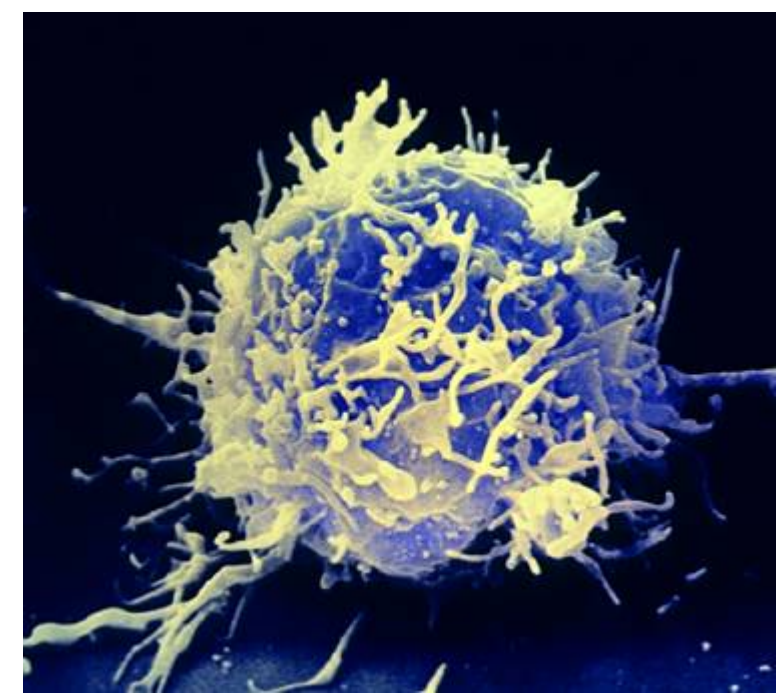

Figura 3: Foto de um Linfócito mostrando várias ramificações em sua membrana celular.

Fonte: http://encarta.msn.com/Lymphocyte.html

\subsubsection{Resposta Imune Adaptativa}

Já a resposta imune adaptativa tem como característica principal o reconhecimento específico de um antígeno que escapou aos controles da resposta inata. A resposta pelo sistema imune adaptativo é antígeno-específica, distinguindo os antígenos self dos não-self no processo de apresentação de antígenos devido à ampla variedade de receptores e suas distinções formadas por polimorfismo. A especificidade antigênica permite a qualidade da resposta imune bem como o desenvolvimento de "memória" imunológica.

Pode-se destacar o conjunto celular dos linfócitos (Figura 3) como sendo as células centrais do Sistema Imune Adaptativo, derivadas das células pluripotenciais hemopoiéticas, originadas da medula óssea. Estas, após reconhecerem um antígeno previamente fagocitado pelas células da resposta inata (monócitos e macrófagos), por meio do processo de apresentação de antígenos específicos, tornam-se ativadas, produzindo citocinas (proteínas que modulam a função de outras células) e multiplicando-se por clonagem (JACHINTO; 2005), com a finalidade de total erradicação do antígeno invasor. Uma das funções do timo e da medula óssea é manter os linfócitos virgens "seqüestrados" em seu interior onde ocorre uma seleção de quais células reagem com moléculas self e não-self através de um processo de amadurecimento dos precursores dos timócitos, população esta que origina os linfócitos. Devido a alta taxa de recombinação dos marcadores self e não-self existentes na superfície de membrana destas células, a expansão de um pool de linfócitos que contém marcadores semelhantes pode conduzir à formação de células com ação auto-imune, identificando o 
próprio Sistema Imune como um agressor externo. Assim, são liberados os que se apresentam no segundo conjunto e os do primeiro são destruídos (ABBAS, LICHTMAN, POBER; 2003).

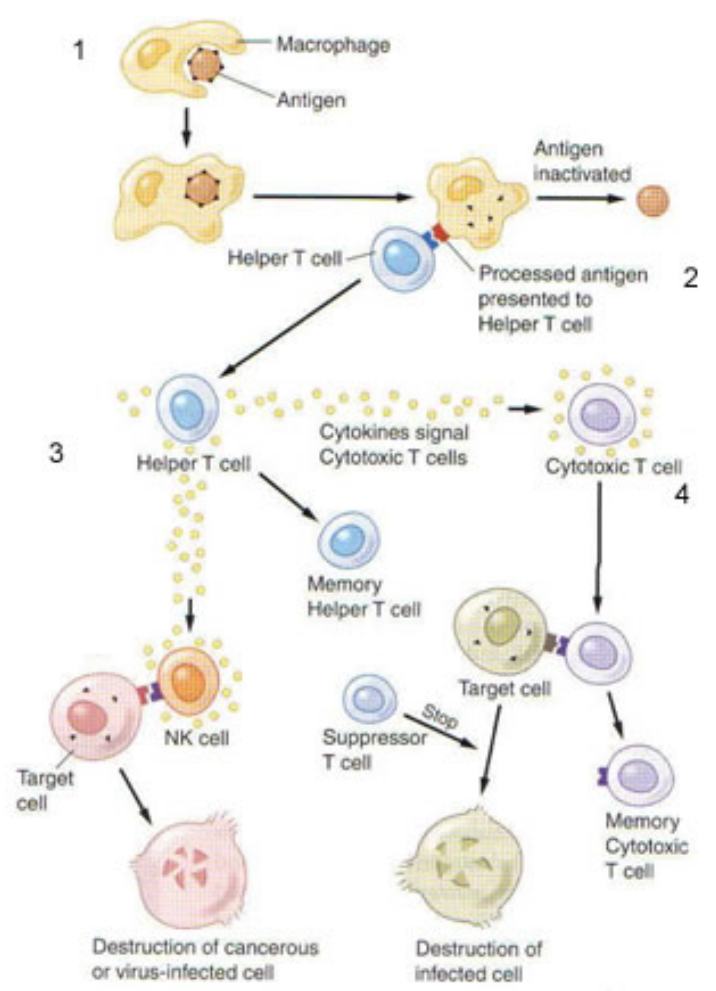

Figura 4: Esquema funcional da ativação dos linfócitos T. (1) Macrófagos ativos fagocitam os corpúsculos estranhos ao nosso corpo (antígenos); (2) Apresentação dos fragmentos destes corpúsculos aos linfócitos T auxiliares (TCD4 ${ }^{+}$); (3) Ativação da resposta imune adaptativa, com os linfócitos TCD4 sinalizando (citocinas) as populações de células Natural Killers, Citotóxicas e Linfócitos B; (4) Linfócitos Citotóxicos (TCD8 ${ }^{+}$) seguem destruindo as células infectadas pelos antígenos.

Fonte: www.nature.com

O processo de apresentação de antígenos (Figura 4) é realizado por células que participam da fagocitose e apresentam fragmentos protêicos do invasor às células linfócito $\mathrm{T}$ e cuja população principal são células denominadas dendríticas, com a função preponderante de capturar e transportar estas moléculas para os nódulos linfáticos (ou linfonodos).A especificidade dos linfócitos $\mathrm{T}$ está ligada ao reconhecimento dos antígenos solúveis bem como daqueles associados às células dendríticas. Esta tarefa recai sobre um grupo de proteínas especializadas, codificadas por genes designados Complexo de Histocompatibilidade Principal (Major Histocompatibility Complex - MHC), possuidor da função fisiológica de apresentação de peptídeos antígenos às células dos linfócitos. Os MHC pertencem a duas classes: Classe I (específicos para TCD4 ${ }^{+}$) e Classe II (específicos para $\mathrm{TCD}^{+}$). Segundo Abbas et al. (2003), o processamento de antígenos trata-se da conversão de proteínas nativas do microrganismo invasor em peptídeos associados ao complexo MHC. Tal 
processo passa por degradação proteolítica das moléculas ou fragmentos peptídicos do invasor (através de conversão intracelular de antígenos protéicos produzidos no citosol) e a apresentação destes para reconhecimento dos linfócitos $\mathrm{T}$, sendo as vias bioquímicas de ativação dos linfócitos $\mathrm{TCD} 4^{+}$e $\mathrm{TCD}^{+}$naturalmente semelhantes.

Em uma primeira etapa, os antígenos transportados pelas células apresentadoras de antígenos (Figura 4) reagem com clones de linfócitos $\mathrm{TCD}^{+}$antígenos-específicos préexistentes nos tecidos especializados que são separados em dois grupos: órgãos linfóides primários e secundários.

Os órgãos primários (Figura 5) são aqueles onde ocorre a maturação e diferenciação dos linfócitos, independente do antígeno (UNANUE, BENACERRAF; 1984), atingindo a maturidade fenotípica e funcional (ABBAS, 2003) e são localizados anteriormente na medula óssea e no timo.

Os órgãos secundários (nódulos linfáticos, baço, sistemas imunes cutâneos e das mucosas) são aqueles onde os antígenos são concentrados e as reações imunes específicas são geradas e desenvolvidas. A ativação e proliferação dos linfócitos T $\mathrm{CD}^{+}{ }^{+}$necessitam da presença de:

(i) antígenos;

(ii) produtos microbianos;

(iii) secreção de citocinas. 


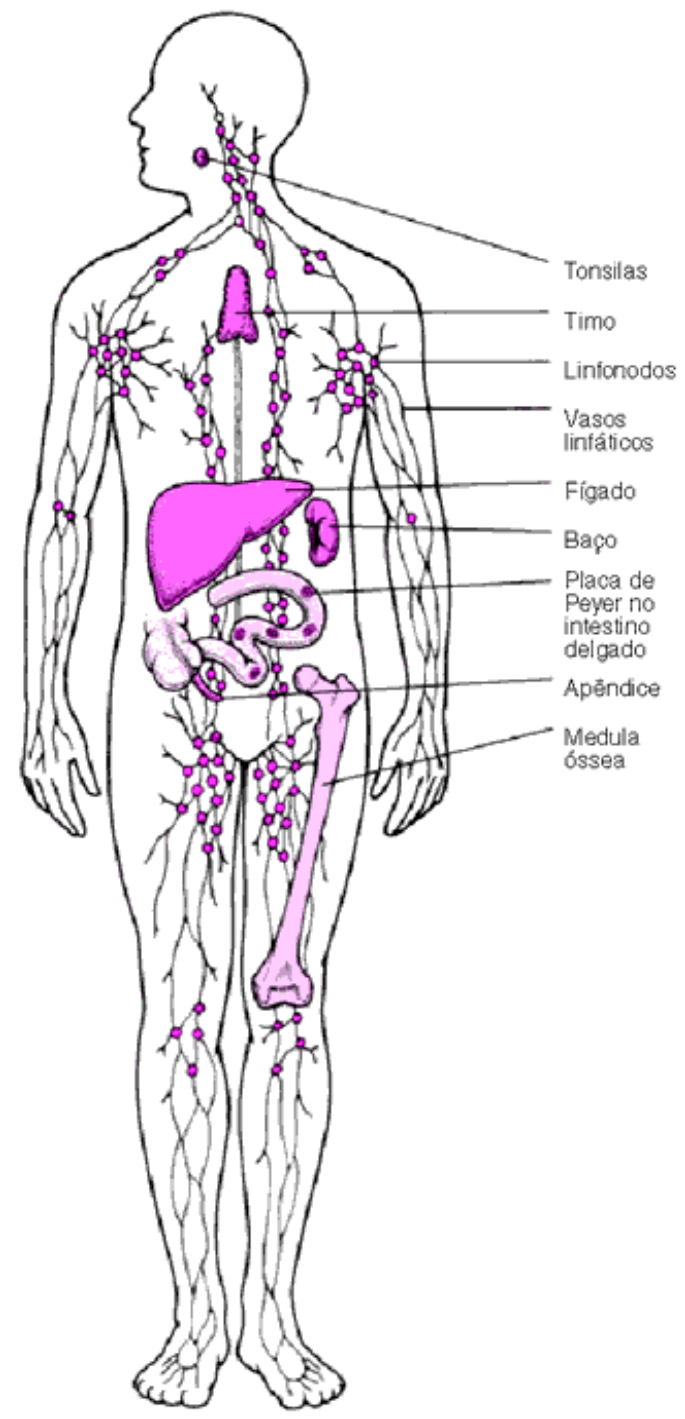

Figura 5: Órgãos linfóides primários e secundários do corpo humano.

Fonte: www.msd-brazil.com/msdbrazil/patients/manual_Merck/mm_sec16_167.htm

O funcionamento do sistema imune contém estruturas hierárquicas de alta complexidade, mas ainda não completamente decifradas, dos mecanismos envolvidos nos diversos níveis de interações compreendendo grupos celulares e diversas moléculas sinalizadoras (citocinas). As células apresentadoras de antígenos com melhor definição são as células dendríticas, os fagócitos mononucleares e os linfócitos B (ABBAS, LICHTMAN, POBER; 2003). O nível da resposta a este tipo de ativação consistirá nas sínteses de novas proteínas sinalizadoras, proliferação celular e diferenciação em células efetoras e de memória. Em todos os processos de diferenciação celular, de maturação ou mesmo do tipo de função exercida pela população de linfócitos, são necessárias moléculas sinalizadoras entre as 
populações de linfócitos e destes com outras populações envolvidas. Estas moléculas são denominadas Citocinas.

\section{Citocinas:}

São moléculas que, anteriormente nos anos 70, eram designadas Interleucinas. Hoje em dia, o termo Citocinas tornou-se um conjunto que engloba, além das interleucinas, os interferons e as quimiocinas. Pode-se dizer que as citocinas compreendem um grupo de famílias de proteínas de baixo peso molecular que assumem o papel de moléculas de comunicação celular exercendo, de certa maneira, o papel de modificadoras das respostas biológicas, atuando de uma forma organizada e complexa sobre proteínas antagonistas, miméticos e proteínas de transporte e, devido à diversidade de receptores celulares, com outras funcionalidades.

As citocinas promovem a ativação e proliferação de outros componentes do sistema imunológico que, por sua vez, se encarregam de produzir anticorpos específicos para aquele antígeno. Os linfócitos $\mathrm{B}$ são mediadores da imunidade humoral e os linfócitos $\mathrm{T}$ são mediadores da imunidade celular. No decorrer deste processo, são formadas células de memória, que respondem de forma mais rápida e eficiente a uma re-infecção, células "regulatórias" deste sistema - linfócitos T regulators ou Treg - que atuam como possíveis inibidores da resposta imune e células NK (Natural Killers), responsáveis pela imunidade inata contra vírus e microrganismos (ABBAS, LICHTMAN, POBER; 2003).

A síntese de novas proteínas sinalizadoras se dá logo após a estimulação, onde os linfócitos ativam genes "silenciosos" para a produção de novas substâncias. Uma vez ativados, os linfócitos passam a crescer por expansão mitótica ou clonal, aumentando o tamanho dos clones (população) e a diferenciação acontece em novas células linfóides com a função de eliminar os antígenos. Um subgrupo formado desta nova população de linfócitos tem a característica de reconhecer e destruir células infectadas e são denominados linfócitos citotóxicos diferenciados (Cytotoxic T Lymphocyte - CTL). Tais células contêm a proteína CD8, reconhecem o complexo MHC I/peptídeo presente em uma célula apresentadora de antígeno e são ativadas possivelmente através de dois mecanismos:

(i) formação de complexos celulares entre os linfócitos $\mathrm{TCD}^{+}$e o antígeno e posterior acoplamento com células linfócitos TCD4 $4^{+}$; 
(ii) formação de um triplo complexo entre as duas células e o antígeno com posterior ativação.

Quando expostos às células que estão infectadas, os linfócitos $\mathrm{TCD}^{+}$liberam citotoxinas através da membrana celular (íons e moléculas tóxicas), lisando as células infectadas ou provocando apoptose e cuja ativação está intimamente relacionada à ativação dos TCD4 $4^{+}$e síntese de IL-2.

Uma vez que os antígenos tenham sido extintos, acontece uma fase de declínio da resposta imunológica, onde uma grande fração de linfócitos ativos sofre apoptose, provavelmente pela ausência de moléculas de antígenos e de fatores de crescimento relacionados aos linfócitos $\mathrm{TCD}^{+}$. Contudo, alguns destes novos linfócitos $\mathrm{T}$ e $\mathrm{B}$ torna-se células "memória", isto é, funcionalmente quiescente, capazes de viver por longos períodos de tempo. Tal fase é denominada homeostase. Estas células de memória podem ser ativadas mais tarde de uma forma mais eficiente e rápida, independentemente da presença de citocinas mediadoras ou sinalizadoras.

\subsubsection{Sistema Imune: Ação na presença do vírus HIV-1}

A Síndrome de Imunodeficiência Adquirida (AIDS) ocorre como conseqüência da ação do vírus HIV no organismo. Esse vírus destrói o sistema imunológico do corpo humano devido ao ataque que realiza às células fundamentais da ativação da resposta imune, os linfócitos TCD4 ${ }^{+}$. Tão logo o vírus HIV-1 entra no corpo, este é rapidamente transportado e disseminado predominantemente em tecidos dos órgãos linfóides pelas mesmas células que estão envolvidas em seu combate: Macrófagos e Células Dendríticas.

$\mathrm{O}$ vírus HIV possui a particular habilidade de invadir determinados tipos de células (fenômeno denominado tropismo) e, para isso, depende de um conjunto de fatores determinados a partir da expressão de moléculas receptoras existentes na parede destas células e que são específicas para o HIV. Este usa um complexo protéico composto de duas glicoproteínas virais (gp120 e gp41) associadas não-convalentemente e presentes no envelope viral. Sabe-se que a porção gp120 do complexo glicoprotêico liga-se com grande afinidade à molécula de superfície CD4 (presente também em células dendríticas e macrófagos). Dois outros receptores quimiocinas, denominados CCR5 (predominantemente expressos nas 
células dendríticas, macrófagos e linfócitos T) e CXCR4 (expressos em linfócitos T ativos), são os principais co-receptores para o vírus.

\section{I.1 - Macrófagos:}

No inicio da infecção aguda, o HIV-1 também infecta monócitos presentes no sangue periférico, macrófagos teciduais e células gliais (semelhantes aos macrófagos) que estão presentes no Sistema Nervoso Central (GORRY, et. al, 2005). É sabido que a progressão desta infecção está fortemente associada à capacidade de replicação viral em macrófagos (Figura 6), essencialmente por dois motivos:

1. Os macrófagos são pouco afetados pelos efeitos citopáticos gerados pelo HIV;

2. Torna-se um "reservatório" de persistente replicação viral (GORRY et al., 2005; AQUARO, 2002) e de difícil combate por ação dos anti-retrovirais.

De acordo com Collman et al. (2003), os macrófagos detém em seu interior citossólico condições onde a replicação viral é inibida (ou conduzida à níveis basais) pela presença da síntese de super-peróxidos, desfavorecendo a evolução genética do HIV-1 durante a Terapia Potente de Anti-retrovirais (HAART), contribuindo possivelmente para o surgimento da cepa selvagem após a terapia inicial ter sido descontinuada. A manutenção da replicação viral, com as variantes de resistência aos medicamentos anti-retrovirais, encontrase na fase assintomática onde existem teores baixos de linfócitos $\mathrm{T}$ e macrófagos residindo em órgãos específicos (cérebro e intestino), de difícil acesso às drogas. Essa replicação viral pode ser iniciada tanto no processo de apresentação de antígenos (pois os macrófagos infectados necessitam serem ativados para produzirem partículas virais) quanto na interação de linfócitos $\mathrm{TCD}^{+}{ }^{+}$infectados com macrófagos em sítios de inflamação, onde o vírus pode infectar de modo endógeno, iniciando sua replicação após a diferenciação (LEE, CH; 2003; SCHRIER, MCCUTCHAN, WILEY, 1993).

O papel que as $\beta$-quimioscinas desempenham durante o processo de infecção viral é de suma importância. Mudanças na síntese de determinadas quimioscinas são observadas no transcorrer da infecção viral, principalmente no cérebro, onde uma grande quantidade destas moléculas e de outros super-peróxidos produzem um desequilíbrio bioquímico característico da demência ligada ao HIV (LEE, 2003). $\beta$-quimioscinas como MIP-1 $\beta$ (CCL4) e SDF-1 $\alpha$ (CXCL12), ligantes naturais do receptor CCR5 e CXCR4 respectivamente, competem com a gp120 por afinidade ao sítio de ligação, impedindo a entrada viral. Entretanto, uma vez que a íntima relação de receptor quimioscina com o CD4 pode modular o mecanismo de apoptose, 
a sinalização por gp120 pode conduzir o linfócito a um quadro anérgico, oposto ao da apoptose, ativando sinais que modulam a replicação viral intracelularmente e favorecendo o escape ao reconhecimento dos linfócitos citotóxicos (LEE, CH; 2003).

A capacidade dos Lentivirus de infectar macrófagos e outras células apresentadoras de antígenos representa uma importante regra no estabelecimento, persistência e patogênese da infecção, conforme mostra Porcheray et al. (2006) e Verani, Gras, Pancino (2005).

A infecção também pode ser influenciada pelo tropismo viral exibido, sendo ou indutores de sincícios (conglomerados celulares e baixa capacidade de replicação em macrófagos) ou não-indutores de sincícios (alta eficiência de infecção em macrófagos) (BouHabib; 2002) ${ }^{4}$ podendo utilizar os receptores quimiocina CCR5 para inoculação do material genético viral.

Todavia, segundo os resultados apresentados pelo trabalho de Gorry e colaboradores (2005), a condição de existência dos receptores CCR5 não é necessária e nem suficiente para que haja o macrófago-tropismo (ou M-tropismo), pois não há conhecimento suficiente para os mecanismos de infecção das variantes X4 (uso do coreceptor CXCR4) e R5X4 do vírus. Contudo, há indícios de que a variante $\mathrm{X} 4$ seja aquela com maior eficiência de infecção em macrófagos (VERANI; GRAS; PANCINO, 2005), coincidindo com a transição entre a fase inicial e intermediária (sintomática) da evolução infecciosa (GORRY et al., 2005). Contrasta com a fase (ou estado) assintomática associada com a variante R5 (BOU-HABIB; 2002) mesmo havendo baixos níveis de moléculas CD4. Smith et al. (2000) associa os baixos níveis de infecção em macrófagos da mucosa intestinal à baixa expressão do co-receptor CCR5 e à alta concentração de CXCR4, provavelmente causada pela ligação de LPS (lipopolissacarídeos) indicando que os teores virais podem estar vinculados à quantidade de linfócitos presentes na mesma mucosa.

\footnotetext{
${ }^{4}$ BOU-HABIB, D C. AidsCongress.net. Rio de Janeiro, 2002 (comunicação pessoal).
} 


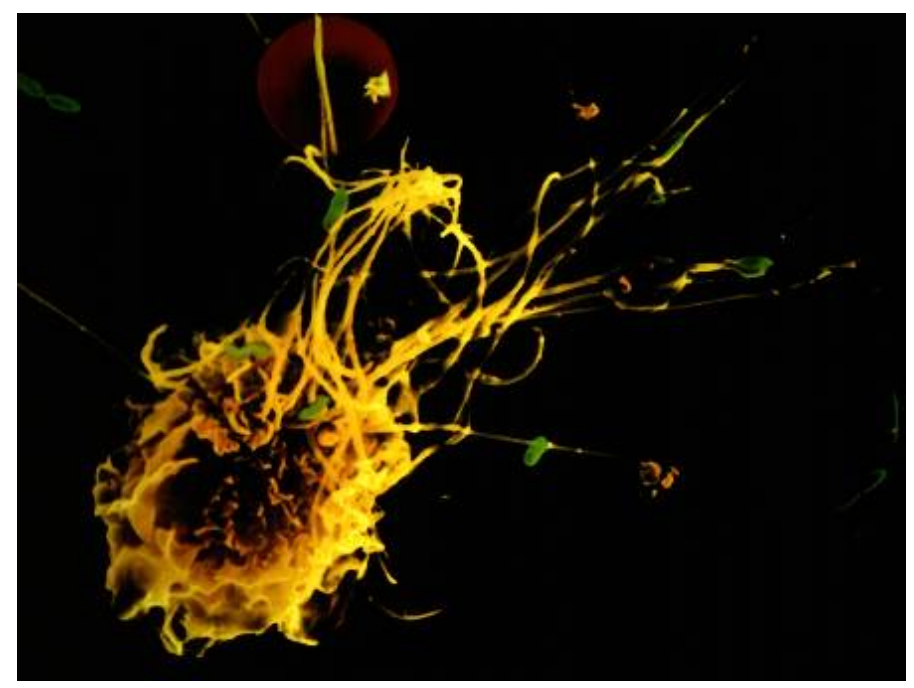

Figura 6: Macrófago no momento de captura e engolfamento de bactérias em seus vacúolos. Fonte: http://encarta.mns.com/Macrophage_Engulfing_Bacterium.html

Durante a infecção aguda, a intensa replicação viral é resultado de uma grande disseminação do HIV e invasão dos linfonodos (ou nódulos linfáticos) transferidos por macrófagos infectados e células dendríticas - processo de apresentação de antígenos (AQUARO et al.; 2002, GORRY et al.; 2005, VERANI, GRAS, PANCINO; 2005) - e que se associam aos linfócitos $\mathrm{CD}^{+}$inativos iniciando o processo de ativação e infecção dos linfócitos existentes.

\section{I.2 - Células Dendríticas:}

Células dendríticas constituem uma população de células apresentadoras de antígenos extremamente potentes, produzidas na medula óssea e presentes em quase todos os tecidos do corpo. São vitais na inicialização das respostas imunes por linfócitos T e, particularmente, por novos antígenos. Sua função é reconhecer estes antígenos e processá-los em peptídeos que são associados ao complexo protêico de histocompatibilidade principal de superfície (MHC) que interage diretamente com o receptor antígeno do linfócito. Além disso, descobriu-se que o complexo celular formado por células dendríticas e o vírus HIV-1, através da ligação de alta afinidade da lecitina SIGN com a glicoproteína gp120, pode infectar linfócitos TCD4 ${ }^{+}$ ativos e outros conjuntos de células dendríticas no interior dos linfonodos, o que se denomina uma “sinapse infecciosa” (MORIS, 2006; GEIJTENBEEK, 2000). 
Recentemente, tem sido mostrado que as células dendríticas são as primeiras a serem encontradas nos locais de inflamação das mucosas (MORIS, 2006). Fauci et al. (1996) relacionam este fato ao início da infecção por HIV, hipotetizando um modelo de inicialização da infecção onde o vírus entraria por um corte ou uma fissura ou sítio de inflamação em uma mucosa, posteriormente conectando-se às células dendríticas ou de Langherans. Em seguida, o complexo resultante (célula dendrítica e HIV) é conduzido até um órgão linfóide, migrando para a região rica em linfócito $\mathrm{TCD}^{+}$. Estes linfócitos são ativados pelas células dendríticas (Figura 7) e são expostos ao HIV, produzindo a infecção e subseqüente disseminação ampla do vírus (WU, KEWALRAMANI; 2006). Entretanto, Marañon et al.(2004) descrevem uma possível rota alternativa de infecção das células dendríticas, diferente da via de apresentação de antígenos, que está correlacionado à transfecção de células apoptóticas, geralmente infectadas, sendo os linfócitos $\mathrm{TCD}^{+}$o maior representante. A possibilidade de existir um mecanismo alternativo de infecção dos linfócitos $\mathrm{TCD}^{+}$, bem como das células dendríticas, pelo vírus HIV-1 estaria relacionado ao fato de que estas células dendríticas funcionariam como "macrófagos especiais" somente para o reconhecimento e apresentação dos fragmentos virais (MARAÑON, 2004).

Embora o mecanismo correto utilizado pelo vírus para a infecção dos linfócitos $\mathrm{TCD}^{+}$naïves não seja conhecido, algumas hipóteses são levantadas. Geijtenbeek et al. (2000) comentam que o mecanismo de reconhecimento e ligação dos linfócitos à célula dendrítica é subvertido pelo vírus onde este utiliza a maior afinidade da gp120 para a SIGN, em relação à ICAM-3 (moléculas de adesão intracelular), ganhando acesso aos linfonodos (através do tráfego de células dendríticas) e aos centros germinativos, onde estão os linfócitos TCD4 ${ }^{+}$. Moris et al. (2006) analisam o fato de que a presença da lecitina SIGN exibe ligação com o complexo Env (viral) com alta afinidade promovendo a apresentação do antígeno pelo complexo MHC II aos linfócitos TCD4 ${ }^{+}$, então, infectando-os com partículas virais. Quando há presença de células expressando SIGN, estas são acompanhadas de um aumento no número de células que expressam IFN- $\gamma$, fato também observado na presença de variantes virais com tropismo R5 e X4.

Contudo, a exposição prolongada ao vírus HIV-1 faz com que as células dendríticas percam a capacidade de ativação e estimulação dos linfócitos, conduzindo a uma diminuição dos níveis de células apresentadoras de antígenos ou reflexo da ação lítica viral ou por ação dos linfócitos citotóxicos $\left(\mathrm{TCD}^{+}\right)$, repercutindo no nível de infecção viral (KNIGHT; EISLEY, WANG; 1997). 


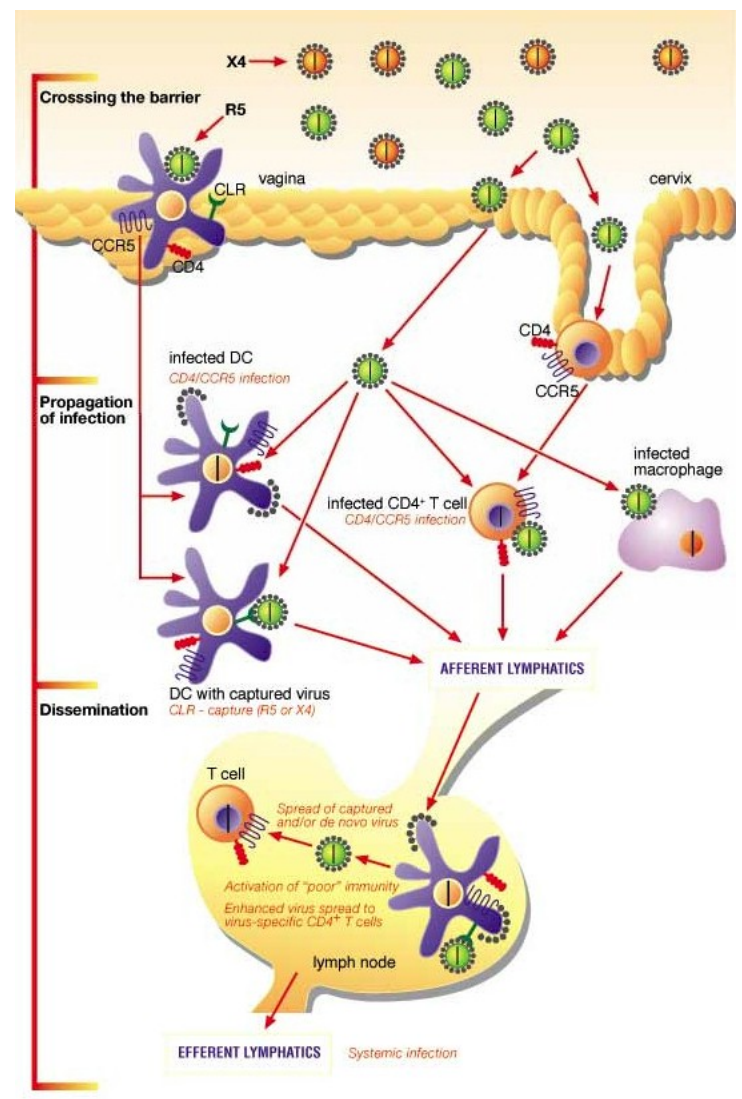

Figura 7: Esquema representativo da implicação das variantes virais no processo de infecção dos linfócitos, células dendríticas e linfonodos. Fonte: POPE, M (2004).

Nos estágios iniciais da infecção, os nódulos linfáticos dos indivíduos infectados estão ativos e muitos virions são aprisionados nos seus centros germinais e extracelularmente nos folículos das células dendríticas (FAUCI et al., 1996). Com a alta taxa de replicação viral, o HIV-1 transportado por macrófagos e células dendríticas internos aos tecidos linfóides periféricos geram sintomas inespecíficos de infecção (ABBAS; LICHTMAN; POBER, 2003).

O período de incubação médio desde a exposição até o surgimento de alguns sintomas é estimado entre 3 a 6 semanas. A produção de anticorpos inicia-se de 8 a 12 semanas após a exposição. 


\section{I.3 - Linfócitos TCD4 ${ }^{+}$:}

Devido ao fato de que o vírus está continuamente preso ao sistema de nódulos linfáticos, inicia-se uma repetida estimulação imune propiciando uma exposição constante à possíveis infecções dos linfócitos $\mathrm{TCD}^{+}$residentes ou que migram através da corrente sanguínea. Tal nível de infecção gera uma aceleração na proliferação celular destas células, chegando a ser 2 ou 3 vezes maior em pacientes não tratados (McCUNE, 2001) e, segundo o trabalho de Jansen, van Baarle, Miedena (2006), o nível prevalente desta ativação imune quando se alcança um equilíbrio é o maior determinante da progressão da AIDS. Em qualquer instante de tempo, admite-se que $0,1 \%$ a $1 \%$ do total de linfócitos $\mathrm{TCD}^{+}$está realmente infectada, com mais de $90 \%$ dos $\mathrm{TCD}^{+}$naïves produtivamente infectados (HAASE, 1999). Após um período estimado de 8 a 15 anos, o organismo fica debilitado pela progressiva destruição de células $\mathrm{TCD}^{+}$e vulnerável às doenças oportunistas. FAUCI e colaboradores avaliaram o papel dos linfócitos $\mathrm{T}$ existentes nos linfonodos e concluíram que havia a presença de níveis detectáveis de carga viral nestes linfócitos quando estimulados com citocinas ou anti-CD3. Como os tecidos linfóides são o maior reservatório de proliferação viral (HAASE, 1999) e a mucosa do trato intestinal é o maior órgão linfóide contendo, também, o maior número de linfócitos e macrófagos em relação a outro órgão do corpo humano (SMITH et al., 2000), a dinâmica da progressão da doença está intimamente ligada com a eficiência da entrada viral e com a formação dos subconjuntos de linfócitos produtivamente e latentemente infectados, de tal forma que o curso final da infecção pode ser aferido pelas condições observadas na fase aguda (6 a 12 meses). De acordo com Walker (2006), a infecção inicial de grande quantidade de linfócitos TCD4 ${ }^{+}$implica uma relação com o pico inicial da viremia e também restringe as respostas subseqüentes adaptativas, mas não relaciona a velocidade de propagação viral. Este processo de rápido "turn-over" celular leva à formação de linfócitos anérgicos ou enfraquecido que não respondem ao processo de ativação por apresentação de antígenos (McCUNE, 2001) e não são erradicados pelos linfócitos CTL (ou $\mathrm{TCD}^{+}$), no caso de estarem cronicamente infectados, fatos também observados por Mohri et al. (2001). 


\section{I.4 - Linfócitos CD4+ “de memória”:}

Os linfócitos TCD4 ${ }^{+}$de memória formam a população remanescente do conjunto de células da resposta imune celular, pois já possuem as características de reconhecimento de antígenos. O genoma viral, integrado ao DNA do hospedeiro, providencia um terceiro tipo de reservatório - juntamente com o reservatório de macrófagos infectados e dos órgãos linfóides repletos de virions - que é de células infectadas cronicamente (SICILIANO; 2006). Linfócitos TCD4 "de memória" que expressam o co-receptor CCR5 são os alvos mais freqüentes do HIV-1 quando não infectados, compondo um repertório restrito de $\mathrm{TCD}^{+}$para combater infecções oportunistas. Juntamente com o subconjunto de linfócitos TCD4 ${ }^{+}$ latentemente infectados, compõem populações produtoras virais com continuada evolução de resistência genotípica às drogas anti-retrovirais (HAASE, 1999).

A sobrevivência deste subconjunto celular depende de mecanismos ainda não determinados, pois é dependente do tamanho do "pool" celular (regulado em equilíbrio ou estado estacionário pelas velocidades de morte celular e replicação), tem sua transição de estado ativado para "memória" efetuada por vias que não necessitam de reconhecimento de antígeno e detém uma maior capacidade de proliferação em relação aos linfócitos TCD4 ${ }^{+}$ naïves (DUTTON, BRADLEY, SWAIN, 1998). A homeostase da sub-população de linfócitos $\mathrm{TCD}^{+}$"de memória" é mediada pela presença e função do receptor IL-7R (KOESTLER et al., 2006). Tal receptor é importante para que haja a ativação do linfócito e aumento da atividade da resposta imune. Todavia, verifica-se que a diminuição (ou queda) no número destes receptores está correlacionada diretamente com a contagem de TCD4+ e inversamente com marcadores de apoptose e de ativação dos linfócitos, porém se mostrou independente da carga viral. A morte celular por ativação (AICD - Activation-induced cell death) não é somente o único mecanismo para a morte dos linfócitos infectados por HIV, pois se manifesta outro mecanismo envolvendo o desequilíbrio da homeostase dos linfócitos através de persistente estimulação das células naïves, empurrando-as ao longo da via de diferenciação, e tornando-se um fator contribuinte da propagação da infecção (KOESTLER et al., 2006).

Na fase de progressão crônica da infecção, a constante estimulação imune acelera a destruição dos linfócitos $\mathrm{TCD}^{+}$e dos tecidos linfóides, principalmente linfonodos e baço, pois à medida que a população de linfócitos é ativada, a transcrição gênica do HIV é facilitada criando novos virions. À medida que o sistema imune tenta erradicar outras infecções presentes, acelera a sua própria destruição (ABBAS, LICHTMAN, POBER; 2003). 


\section{I.5 - Linfócitos TCD8 ${ }^{+}$ou CTL:}

$\mathrm{Na}$ fase de infecção aguda (ou primária), observa-se um aumento no número absoluto de linfócitos $\mathrm{TCD}^{+}$circulantes na resposta imune (com inversão da relação $\mathrm{CD} 4^{+} / \mathrm{CD} 8^{+}$) contribuindo para a defesa do hospedeiro. Sua presença pode ser detectada antes do aparecimento de anticorpos neutralizantes e algumas vezes permanece nestes altos níveis através dos estágios clinicamente latentes da infecção (CASTELLINO, GERMAIN. 2006). A constante replicação viral destrói o material tecidual dos órgãos linfóides, fato que pode estar correlacionado com a queda progressiva de linfócitos $\mathrm{TCD}^{+}$naïves (ou virgens) que migram para a corrente sanguínea. Os linfócitos $\mathrm{TCD}^{+}$(também denominados $\mathrm{CTL}$ ) são ativados no momento da apresentação de antígenos possivelmente por dois mecanismos: (i) ou diretamente pelo antígeno; (ii) ou por formação de complexo $\mathrm{TCD}^{+}$e célula apresentadora de antígenos (ROUZINE, SERGEEV, GLUSHTOV; 2006, CASTELLINO, GERMAIN; 2006 e ABBAS, 2003). A proliferação de TCD8+ antígeno-específico ocorre entre um e um dia e meio após a introdução do antígeno e, uma vez ativado, não necessita de outro procedimento (presença de $\mathrm{TCD}^{+}$antígeno-específico) para emergência de células completas “de memória" algumas semanas depois. Castellino e Germain (2006) comentam sobre a possibilidade de haver outro processo mediado por citocina que mantém a viabilidade celular.

Sabe-se que a maioria dos vírus encontrados nos pacientes é advinda de células $\mathrm{TCD}^{+}$infectadas e de vida curta (aproximadamente dois dias) e a imunidade protetora depende da geração e manutenção do repertório de linfócitos $\mathrm{T}$ de memória $\mathrm{e}$ da sobrevivência de tais células por longos períodos de tempo após o contato inicial com o antígeno (CUNHA et al.; 2006).

\section{I.6 - Vírus HIV-1:}

Como mencionado no item anterior, uma vez que o indivíduo tenha estado em contato ou seja infectado através de relação sexual desprotegida ou por uso de seringas e/ou sangue contaminados, o vírus se encarrega de sobreviver por intermédio de interações celulares e protêicas com as células envolvidas, de macrófagos a linfócitos (Figura 8). 


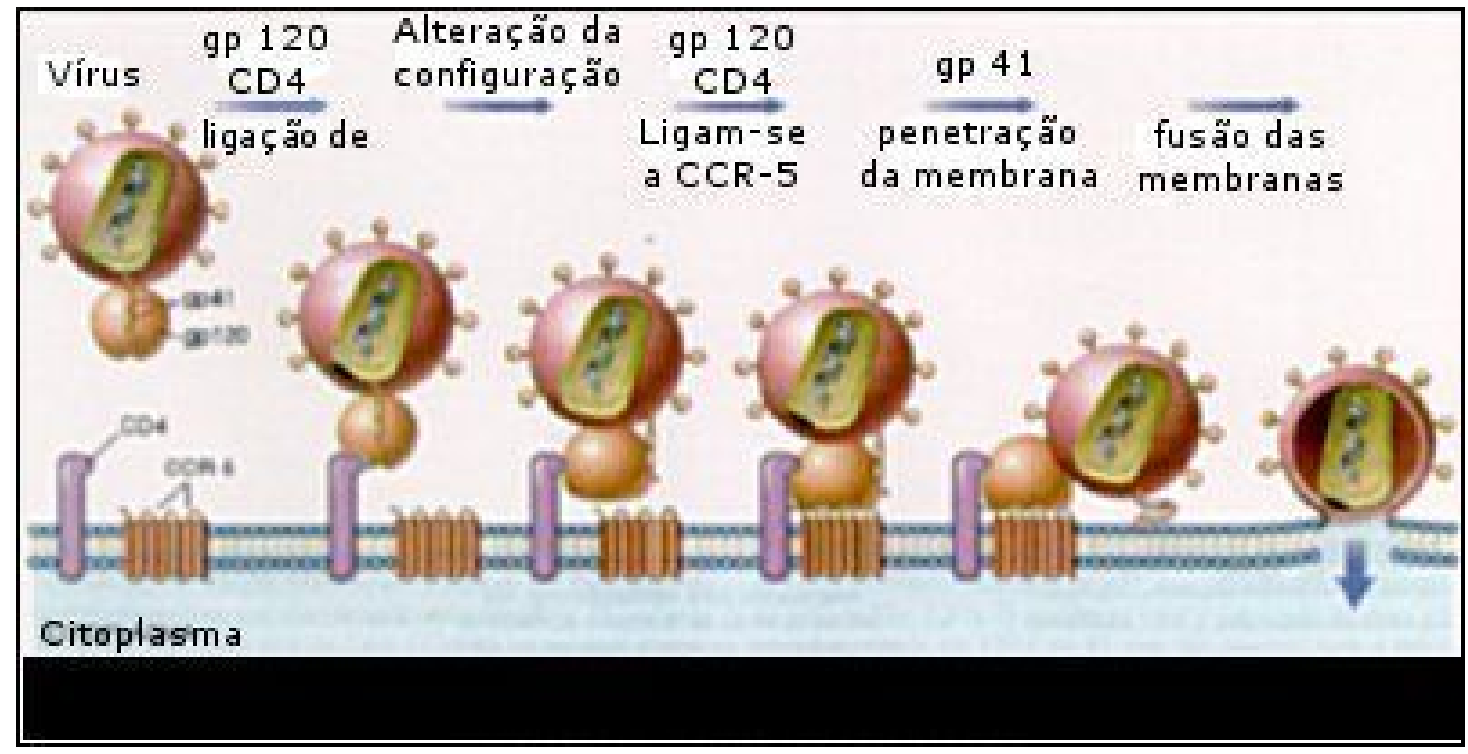

Figura 8: Esquema que mostra o processo de acoplamento, ancoragem e invasão do vírus HIV no linfócito TCD4 $4^{+}$.

Fonte: www.ajc.pt/cienciaj/n23/invivo.php

Para tanto, possui em seu arsenal uma glicoproteína de envelope (denominada Env) que é produto do gene de mesmo nome. Tal glicoproteína é separada em dois subdomínios, um subdomínio de superfície (denominado gp 120 ou SU) e outro com ação trans-membrana (gp 41 ou TM) que, como as proteínas oriundas dos genes gag e pol, estas glicoproteínas são resultados da clivagem de uma grande poliproteína.

A gp120 é uma proteína altamente glicosilada, localizada no exterior da partícula viral. Não possui nenhum domínio transmembrana sendo ligada não-convalentemente (isto é, levemente) à gp41 formando um oligômero. Nos diversos subtipos de HIV, a seqüência codificante da glicoproteína varia consideravelmente em 5 principais domínios, dos quais o domínio V3 é o mais importante (este domínio detém uma seqüência conservada de aminoácidos GPGRAF) e sua variação repercute na escolha da célula hospedeira e nas interações da gp120 com os receptores quimiocinas. O mais importante é que a gp120 liga-se com alta afinidade às proteínas celulares CD4 e, em seqüência, aos receptores quimiocinas (notadamente os CCR5) em um sub-domínio de ligação bem conservado.

A gp41 possui uma pequena região estirada composta de resíduos altamente hidrofóbicos, denominado "domínio de fusão", que servem como âncora para a ligação à membrana lipídica do envelope viral por ação de mudança conformacional desta glicoproteína e dos co-receptores, resultando na formação de uma estrutura coiled-coil permitindo a fusão das membranas virais e celulares (Figura 9). 


\subsubsection{Receptores Quimiocinas e o tropismo X4 e R5:}

As cepas R5 utilizam os co-receptores CCR5 (receptor 5 composto de quimiocinas Cisteína-Cisteína), que é encontrado em células dendríticas, macrófagos e linfócitos $\mathrm{T}$, predominando em infecções iniciais e acredita-se ser a principal espécie envolvida na transmissão por via sexual através da mucosa.

As cepas X4 usam o co-receptor CXCR4 (existe um aminoácido X entre as duas Cisteínas no receptor 4) para infecção somente dos linfócitos $\mathrm{T}\left(\mathrm{TCD} 4^{+}\right)$predominando ao longo da infecção e está associado com a eliminação destas células. 

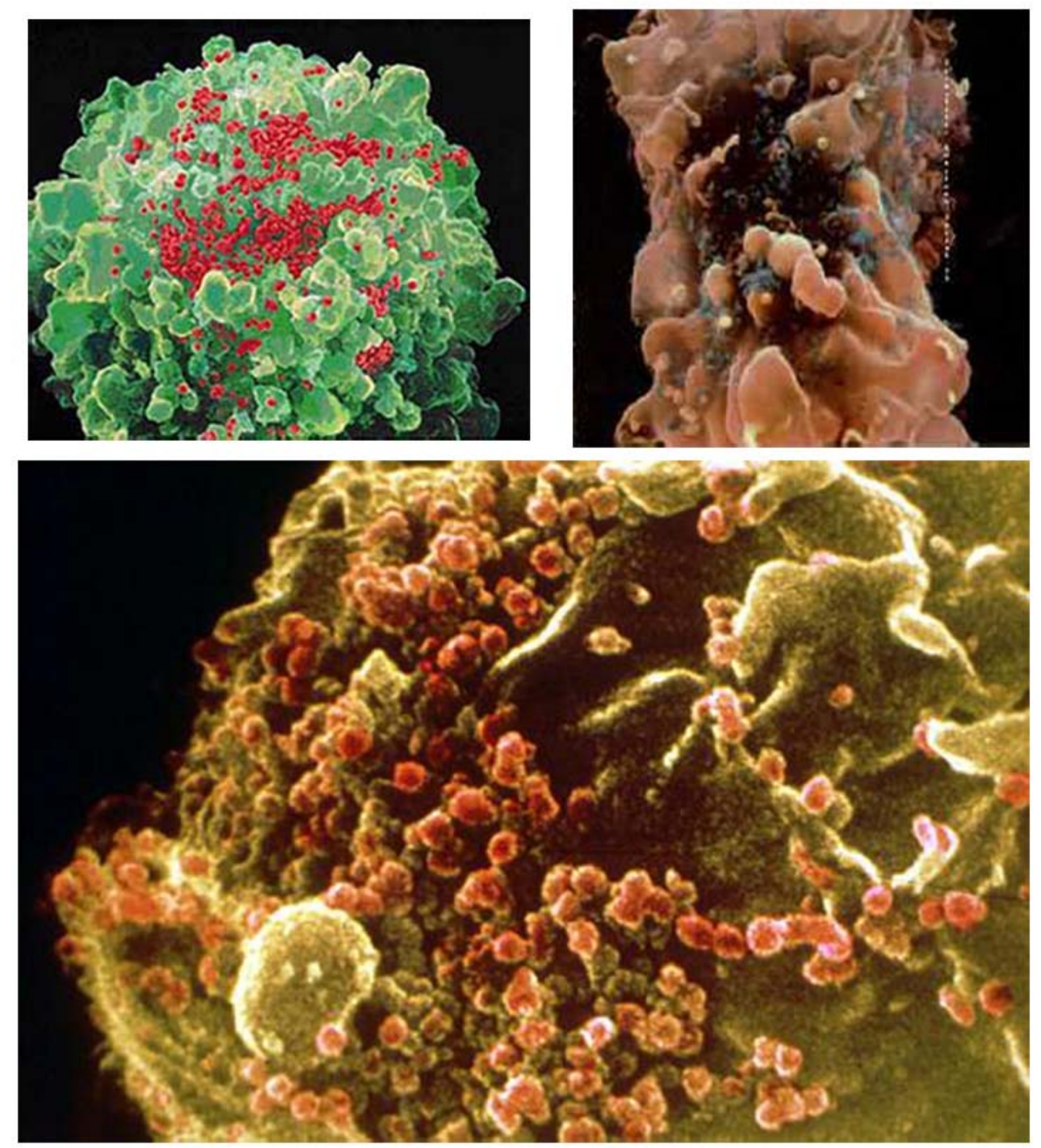

Figura 9: Fotos em microscopia de varredura, que foram coloridas posteriormente, mostrando a aproximação e conecção dos vírus HIV à membrana celular dos linfócitos TCD4 ${ }^{+}$, mostrando a relação de tamanho, a quantidade e o processo de brotamento.

Fonte: (a) encarta.mns.com/T-lymphocyte_infected_with_HIV.html; (b)

biology.ucsd.edu/classes/bicd140.SP07; (c) www.wellesley.edu/Chemistry/Chem101/hiv/tcells-hiv.jpg 


\subsection{Modelos Matemáticos}

Segundo Ferreira Jr, W.C (2002) ${ }^{5}$, um modelo matemático dinâmico não tem por objetivo apenas descrever a história passada do sistema, mas sim prever os estados futuros e ainda não observados do sistema. Assim, o modelo matemático deve estabelecer uma dinâmica que determine as populações (quantidade de indivíduos) futuras, uma vez conhecidas as populações atuais.

Em outro parágrafo, definiu a Dinâmica das Populações como sendo uma poderosa síntese matemática que permite identificar, transferir e interfertilizar diversas teorias da Biologia Teórica, desde o nível molecular em Processos Físico-Químicos, passando pelo nível celular em Fisiologia e chegando à Epidemiologia de organismos superiores.

A última década tem mostrado um dramático aumento de ocorrências ligadas às doenças infecciosas, segundo a perspectiva da Saúde Pública. Tal tendência é devido à emergência de infecções novas e altamente patogênicas, tal qual Ébola, vírus do oeste do Nilo e SARS, além de doenças com alta taxa de proliferação e economicamente custosas, como a Febre Aftosa. O controle e a administração efetiva destas infecções (ou epidemias) é feito, efetivamente, através do input substancial de modelos matemáticos, usados não somente para prover informações relativas à doença em si mas também para estimativas de parâmetroschave e de decisões alternativas de contenção.

Quando se fala de modelos epidemiológicos, principalmente os determinísticos, os indivíduos pertencentes a uma população sob investigação são divididos em um número de classes ou compartimentos que depende da complexidade das interações entre eles e do objetivo do estudo. Indivíduos suscetíveis que são expostos à doença podem migrar ao estado infectado ou ao estado latentemente infectado (ou infeccioso) de acordo com uma taxa de infecção. Do estado infectado (ou do infeccioso), estes indivíduos migram para o compartimento de recuperados por ação de estímulos imunológicos ou por tratamento medicamentoso. Porém, para algumas doenças, indivíduos que estão no compartimento de recuperados podem reverter-se ao quadro patogênico anterior e migrar novamente para o compartimento dos infectados, levando a uma possível ressurgência da epidemia, um fato que passa a ser importante nos estudos de Tuberculose e Herpes, por exemplo. Um dos triunfos da Epidemiologia Matemática foi a formulação do modelo de Kermack-McKendrick em 1927 (HUANG, VILLASANA; 2005; KERMACK, MCKENDRICK (1991) ${ }^{6}$ apud BRAUER;

\footnotetext{
${ }^{5}$ Obtido em http://www.comciência.br/reportagens/modelagem/mod16.htm . Disponível em Abril/2007.

${ }^{6}$ Kermack; McKendrick. Bulletin of Mathematical Biology, v. 53, n. 1-2, p. 33-55, 1991.
} 
2005), que separou a população sob estudo em dois compartimentos: um para suscetíveis e outro para infectados, para estudo da progressão da infecção de cólera e de peste (Londres e Bombaim durante os anos de 1665 e 1666). Mais tarde, este modelo foi utilizado com sucesso em vários processos epidêmicos. Outro modelo foi de Anderson e May (ARDERSON, MAY; 1988) que analisou e simulou fatores ligados à progressão da AIDS e a ligação destes com parâmetros epidemiológicos da população estudada.

A chance de a epidemia prevalecer sobre a população estudada e esta, por sua vez, vir a tornar-se infectada e diminuir por morte ocasionada pela doença é mostrada pelo Número de Reprodutibilidade Basal $-R_{0}$ - o qual é definido como o número de infecções secundárias causadas por uma infecção simples, introduzida em uma população suscetível, dentro do intervalo de tempo onde ocorre esta infecção simples (BRAUER; 2005).

No caso do Sistema Imune, as interações não-lineares entre os componentes celulares e moleculares podem salientar comportamentos que não são intuitivos e nem preditos através das propriedades dos componentes individualmente. Uma compreensão mais aprofundada pode ser adquirida por meio de análises matemáticas dessas interações, investigando as propriedades do Sistema Imune envolvidas no comportamento biológico. As decisões sobre quais componentes deverão ser incluídas no modelo dependem, sobretudo, das dúvidas inerentes ao processo imunológico e do sistema sob investigação (CALLARD, YATES; 2005). Nos últimos anos, vários estudos tem sido dedicados a compreender o spread das doenças infecciosas, principalmente a Síndrome de Imunodeficiência Adquirida (AIDS), que emergiu em 1981 e tem se tornado uma importante doença transmitida em todo o mundo. Em conseqüência, vários modelos matemáticos foram desenvolvidos para descrever as relações entre o HIV-1 e sua célula alvo, o linfócito TCD4 ${ }^{+}$(CIUPE et al.; 2006, JONES, PERELSON; 2005, CULSHAW; 2002, PERELSON; 2002). Geralmente, estes modelos estão agrupados de acordo com foco da análise do trabalho em si e de sua atuação; seja na aplicação de metodologias dos sistemas dinâmicos, como formas de equilíbrio ou sensibilidade do conjunto de equações, ou características e resultados de tratamentos com drogas antiretrovirais.

Os modelos matemáticos desenvolvidos para representar a dinâmica da infecção e interação do vírus HIV com o sistema imune são formados, basicamente, da população de linfócitos $\mathrm{TCD}^{+} \mathrm{e}$, em alguns casos, a presença de outras populações, como o CTL (FRASER, FERGUNSON, ANDERSON; 2001, de SOUZA; 1999), macrófagos (De BOER, 
HOGEWEG 1986; De BOER et al. 1985) ou células dendríticas. Geralmente são compostos por um conjunto de equações diferenciais não-lineares (VEROTTA; SCHAEDELI; 2002) ou de equações diferenciais recursivas (HLAVACEK et al. 2002; HLAVACEK, STILIANAKIS, PERELSON; 2000) e ainda com termos de atraso em seus respectivos fluxos (COUTINHO et al., 2006; MASSAD et al., 2001). Como os processos bioquímicos intracelulares não ocorrem imediatamente mas em diferentes instantes de tempo de acordo com a cinética metabólica envolvida, modelos matemáticos que incluem atrasos em sua estrutura tornam-se mais realistas por melhor representar os tempos de incubação (CULSHAW, RUAN, WEBB; 2003) provenientes de uma infecção - viral ou bacteriana - ou a transição de um fenômeno à um outro de grande relevância (WEI, ZOU; 2006).

No Departamento de Patologia da Faculdade de Medicina da Universidade de São Paulo, mais precisamente no grupo que compõe a Disciplina de Informática Médica (DIM), são gerados trabalhos de Dinâmica das Populações em um enfoque de Epidemiologia dentro de aspectos variados, ora priorizando a vacinação em surtos de Febre Amarela (MASSAD et al., 2005) ou em casos de soropositivos infectados com HIV (MASSAD et al., 2006), ora priorizando as condições de Threshold (COUTINHO et al., 2006) de uma possível epidemia ou a proliferação de moléstias, como Rubéola (MASSAD et al.,1994) e Influenza (MASSAD et al., 2007). A linha de pesquisa que aborda o tema de HIV/AIDS, onde se vê uma multidisciplinaridade dos pesquisadores envolvidos, são publicados trabalhos com relação a sua dinâmica, prevalência e eficiência dos esquemas de tratamento (LOPEZ, L F et al.; 2006, 2002) até o uso de Teoria das Probabilidades no estudo e compreensão das mutações gênicas do vírus HIV-1 subtipo F1 encontradas no Estado de São Paulo (OLIVEROS, 2005). 


\subsection{Objetivos principais}

No presente trabalho, foi elaborado um modelo matemático com a intenção de representar a dinâmica da infecção pelo vírus HIV-1, sob enfoque da dinâmica do Sistema Imune, durante o progresso da doença no paciente. Para isso, o objetivo foi separado em etapas:

1. Representar as possíveis influências de cada compartimento relacionado ao Sistema Imune do paciente na interação direta com o vírus HIV-1 como também alguns mecanismos bioquímicos importantes, presentes nos períodos de respostas imunológicas inatas e adaptativas;

2. Mostrar a possibilidade de haver progressão da infecção viral, mesmo que se observe capacidade citotóxica dos linfócitos $\mathrm{TCD}^{+}$, por intermédio do "Número de Reprodutibilidade Basal” $\left(R_{0}\right)$. 


\section{Materiais e Métodos}

\subsection{Descrição das equações do Modelo Matemático}

Basicamente, quando se apresenta uma infecção (seja por bactéria ou vírus), a reação do organismo é voltada para impedir sua continuidade e fazer retroceder tal invasão. Isso, como já foi visto no capítulo da Revisão Bibliográfica, acontece pelo fato de haver uma barreira celular e química bloqueando a invasão, instalação e a proliferação de tal infecção. Sabe-se que as populações de células macrófagos e células dendríticas estão grandemente envolvidas nesta fase da defesa e que são suscetíveis à infecção pelo HIV-1.

De acordo com a literatura pertinente, os principais conjuntos celulares que tem contato com a partícula viral, tanto no momento inicial da infecção quanto nos períodos subseqüentes (fases assintomática ou crônica e AIDS), são listados no Quadro 1 abaixo:

Quadro 1: Apresentação dos compartimentos adotados para o modelo

\section{Compartimentos adotados \\ Referências}

\begin{tabular}{|l|l|}
\hline \multirow{3}{*}{ Macrófagos } & $\begin{array}{l}\text { VERONI, GRAS, PANCINO (2005);GORRY et al. (2005); } \\
\text { AQUARO et al. (2002); MONTANER, PERNO, CROWE } \\
\text { (2000); SCHRIER, McCUTCHAN, WILEY (1993); COLLMAN } \\
\text { et al. (1989) }\end{array}$ \\
\hline Células dendríticas & $\begin{array}{l}\text { WU, KEWALRAMANI (2006); STEBBING, BOWER (2006); } \\
\text { MORIS et al. (2006); GEIJTENBEEK et al. (2000); } \\
\text { HLAVACEK et al. (2002); VANHAM et al. (2000); } \\
\text { HLAVACEK, WOFSY, PERELSON (1999) }\end{array}$ \\
\hline $\begin{array}{l}\text { Linfócitos TCD4+e e } \\
\text { Carga Viral }\end{array}$ & $\begin{array}{l}\text { JANSEN, van BAARLE, MIEDEMA (2006); CASTELLINO, } \\
\text { GERAIN (2006); WALKER, BD (2006); FRASER et } \\
\text { al.(2002); McCUNE, JM (2001); MOHRI, et al. (2001); SMITH } \\
\text { et al. (2000), HAASE, AT (1999); DUTTON, BRADLEY, } \\
\text { SWAIN (1998), FAUCI et al. (1996) }\end{array}$ \\
\hline $\begin{array}{l}\text { Sinfócitos TCD8+ } \\
\text { ou Citotóxicos }\end{array}$ & $\begin{array}{l}\text { ROUZINE, SERGEEV, GLUSHTOV (2006); ASQUITH et al. } \\
\text { (2006); ROUZINE, MURALI-KRISHNA, AHMED (2005); }\end{array}$ \\
ANTIA, GANUSOV, AHMED (2005); WICK et al. (2005); \\
FRASER, FERGUNSON, ANDERSON (2001).
\end{tabular}

Transportando as idéias apresentadas por COUTINHO et al. (2006) para o conjunto de equações diferenciais representativas dos fluxos de linfócitos TCD4 ${ }^{+}$, pretendeuse mostrar a variação desta população nos vários períodos de infecção (aguda, assintomática, sintomática e AIDS). Nas demais populações representadas - macrófagos e células 
dendríticas - este artifício de atraso temporal não foi empregado devido a fatos pouco conclusivos apresentados em literatura. Na população de linfócitos $\mathrm{TCD}^{+}$, a subpopulação de $\mathrm{TCD} 4^{+}$produtivamente infectados aparece após um atraso característico, compreendendo desde o intervalo de tempo onde ocorre o acoplamento viral aos receptores de membrana até a introdução e estabilização do material genético viral ao material do hospedeiro. Tal atraso é de, aproximadamente, um dia para a população de linfócitos produtivamente infectados e de 15 a 20 dias para a subpopulação de $\mathrm{TCD}^{+}$latentemente ou cronicamente infectados (MITTLER et al., 1998; HERZ et al., 1996). Nestas equações, a probabilidade que o vírus tem de entrar na célula, uma vez que ele esteja acoplado aos receptores CD4 e co-receptores quimiocina, foi modelada de acordo com a Teoria das Filas, considerando que o processo de chegada possa ser aproximado a uma distribuição de Poisson com média $1 / \gamma$. A esperança de vida do HIV-1 livre no sangue admite-se ser igual à $1 / \gamma$, decaindo exponencialmente ao longo do tempo de infecção. Os demais vírus sobreviventes que alcançam alguma membrana de linfócito $\mathrm{TCD}^{+}$possuem a probabilidade $(1-\exp (-\gamma t)) / \gamma$ de não sofrerem "clearance". Se cada partícula viral que encontra uma célula $\mathrm{TCD}^{+}$faz contato em uma dada proporção $a$, então se pode dizer que a probabilidade total de um vírus HIV-1 de se conectar à membrana $\mathrm{e}$ invadir a célula linfócito $\mathrm{TCD}^{+}$é de $a^{*}(1-\exp (-\gamma t)) / \gamma$, ou seja, a proporção de vírus sobreviventes no sangue multiplicado pela probabilidade de contato entre a célula e a partícula viral (a). A forma de representação matemática do processo de apresentação de antígenos é semelhante àquela de McDonalds para a malária (MASSAD et al., 1994; MACDONALD; 1952).

Outra hipótese adotada foi que o processo de apresentação de antígenos pode ser realizado tanto pelos macrófagos infectados quanto pelo conjunto formado por célula dendrítica-HIV, não considerando a possibilidade da formação de sincícios celulares devido ou ao subtipo viral ou à formação de células polinucleadas que contêm partículas virais em seu interior (típico de macrófagos ativos e infectados) (ROSSI; LOPEZ, 2007).

A formação destes aglomerados celulares dificulta a penetração de medicamentos e leva a um "santuário" de proliferação viral no paciente. Este fato é decorrente das características metabólicas e bioquímicas do macrófago, implicando diretamente na eficiência dos anti-retrovirais (PERNO et al., 2006; AQUARO et al., 2005). Como característica decorrente deste fato, os autores citam a formação de vírions com seqüências genéticas ou splicing alternativos do RNA diferentes daqueles sintetizados nos linfócitos TCD4 ${ }^{+}$, com menor variabilidade gênica em relação aos vírus resistentes às drogas anti-retrovirais. 


\subsection{Descrição do Conjunto de Equações}

O enfoque matemático desenvolvido neste modelo considera, envolvidos no processo de infecção e proliferação viral, apenas cinco populações, quais são: Macrófagos, Células dendríticas, Linfócitos TCD4 ${ }^{+}$e CTL e os vírus HIV-1.

As influências que os compartimentos e fluxos sofrem podem ser vista no diagrama da Figura 10. Nele, verifica-se a importância do compartimento de linfócitos TCD4 ${ }^{+}$, cuja variação induz uma resposta no comportamento dos demais compartimentos, seja de macrófagos, células dendríticas ou dos linfócitos CTL, em consonância com os mecanismos de controle do sistema imune (ABBAS, LICHTMAN, POBER; 2003). A confecção do modelo se inicia com algumas premissas:

(i) A população de macrófagos já reconheceu a presença de patógenos no organismo e, portanto, já está em estado ativado;

(ii) Células dendríticas ainda não entraram no processo de diferenciação diferenciando-se em células maduras e infectadas no transcorrer do processo de apresentação de antígenos;

(iii) Nos compartimentos de linfócitos $\mathrm{TCD}^{+}$e CTL, há um fluxo constante de entrada de células, provenientes do timo;

(iv) A população de $\mathrm{TCD} 4^{+}$tem um crescimento dependente do estímulo obtido pela apresentação de antígenos e de sua ativação. As subpopulações descendentes do $\mathrm{TCD}^{+}$são frações proporcionais à quantidade total deste. 


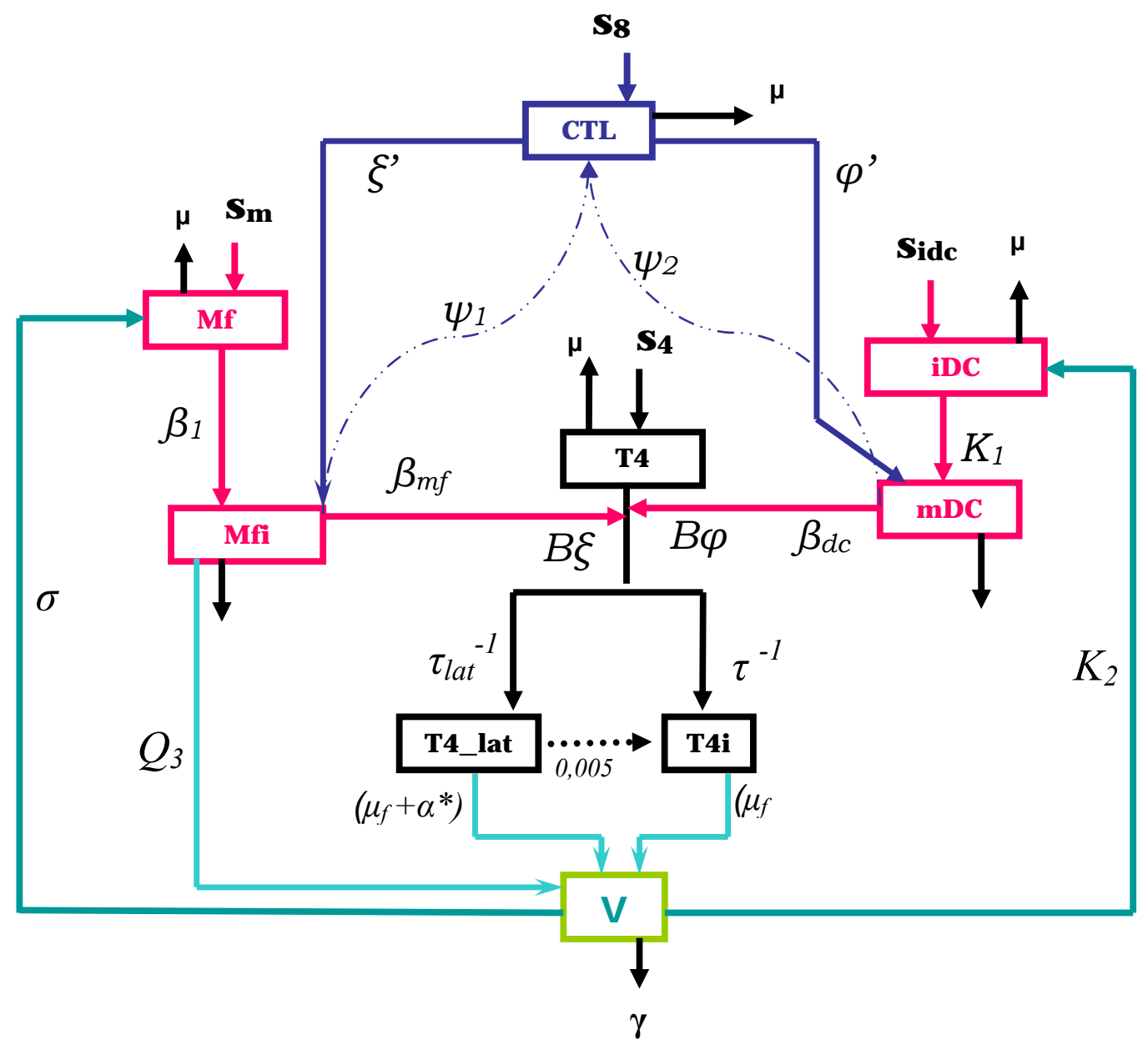

Figura 10: Fluxograma esquemático do funcionamento do Sistema Imune quando da presença do vírus HIV.

Uma vez que o patógeno (neste caso o HIV) invade o corpo humano, a primeira barreira celular encontrada é a população de macrófagos que, ao reconhecerem a sua presença, sinalizam aos linfócitos e proliferam em uma taxa $\ell_{1}$. Nesta proliferação celular, entram em contato com o HIV segundo uma taxa de saturação dada pela função $v^{n} /\left(v^{n}+K_{v}\right)$ (resposta tipo II de Holling). Esta função leva um expoente, semelhante ao expoente de Hill (VOET, VOET, 2004; CHAUDHRY et al., 2004), devido a uma provável atividade de cooperação entre as interações celulares do HIV $(v)$ e dos macrófagos ativos $(M f)$. Os macrófagos ativos nascem com um fluxo constante $s_{m}$ e morrem de causas naturais em uma taxa $\mu_{f}$ (Equação 1).

A transição dos macrófagos pertencentes aos compartimentos do estado ativo para o estado ativo e infectado (Equação 2 ) se dá através de uma probabilidade $\beta_{1}$ dos encontros virais, levando à uma taxa de formação dos macrófagos ativos e infectados de $\beta_{1}\left(v^{n}\right)\left(v^{n}+\right.$ $\left.\left.K_{v}\right)\right) M f$. 


$$
\begin{aligned}
& \frac{d M f}{d t}=s_{m}+l_{1} M f-\beta_{1} M f \frac{v^{n}}{v^{n}+K_{v}}-\mu_{f} M f \\
& \frac{d M f i}{d t}=\beta_{1} M f \frac{v^{n}}{v^{n}+K_{v}}-\left(\mu_{f}+\alpha^{\prime}\right) M f i-\beta_{m f} M f i . T 4-\psi_{1} C T L . M f i \\
& \frac{d(i D C)}{d t}=s_{i d}+l_{2} . i D C-K_{1} i D C \frac{v}{v+\kappa_{v}}-\mu_{i d} i D C \\
& \frac{d(m D C)}{d t}=K_{1} i D C \frac{v}{v+\kappa_{v}}-\mu_{d c} m D C-\beta_{d c} m D C . T 4-\psi_{2} C T L . m D C \\
& \frac{d T 4}{d t}=s_{4}+\left[\beta_{m f} M f+\beta_{d c} m D C\right] T 4-\operatorname{tax} *\left(\frac{1-e^{-\gamma t}}{\gamma}\right) T 4(\xi M f i+\phi m D C)-\mu T 4 \\
& \frac{d T 4 i}{d t}=z^{*} \operatorname{tax} *\left(\frac{1-e^{-\gamma t}}{\gamma}\right) T 4(t-\tau)(\xi . M f i(t-\tau)+\phi \cdot m D C(t-\tau)) e^{-\left(\mu+\alpha^{*}\right) \tau} \\
& -\left(\mu+\alpha^{*}\right) T 4 i+0,0005 T 4 \text { lat }-\psi_{3} \text { CTL.T4i } \\
& \frac{d T 4 l a t}{d t}=(1-z) * \operatorname{tax} *\left(\frac{1-e^{-\gamma t}}{\gamma}\right) T 4\left(t-\tau_{\text {lat }}\right)\left(\xi . M f i\left(t-\tau_{\text {lat }}\right)+\phi . m D C\left(t-\tau_{\text {lat }}\right)\right) e^{-\left(\mu+\alpha_{\text {lat }}^{*}\right) \tau_{\text {lat }}} \\
& -\left(\mu+\alpha_{\text {lat }}^{*}\right) \text { T4lat }-0,0005 \text { T4lat } \\
& \frac{d C T L}{d t}=s_{8}-\mu_{c t l} C T L-\left(\xi^{\prime} M f i+\phi^{\prime} m D C\right) C T L+\left[\psi_{1}^{c t l} \cdot M f i+\psi_{2}{ }^{c t l} \cdot m D C+\psi_{3}{ }^{c t l} \cdot I\right] C T L \\
& \frac{d v}{d t}=Q_{1}\left(\mu+\alpha^{*}\right) T 4 i+Q_{2}\left(\mu+\alpha_{\text {lat }}^{*}\right) T 4 l a t+Q_{3} M f i-K_{2} . i D C \cdot v-\sigma M f \cdot \frac{v^{n}}{v^{n}+K_{v}}-\gamma v
\end{aligned}
$$

No processo de apresentação de antígenos, o número de contatos que os macrófagos infectados realizam com linfócitos $\mathrm{TCD}^{+}$é $\beta_{m f} M f_{i}$, onde $\beta_{\mathrm{mf}}$ é a probabilidade de um macrófago infectado encontrar uma célula linfócito $\mathrm{TCD}^{+}$naïve. Portanto, a contribuição destes contatos para a variação da população de linfócitos $\mathrm{TCD}^{+}$é $\beta_{m f} M f_{i . T 4}$. Como o macrófago ativo e infectado não é suscetível aos efeitos citotóxicos do HIV, sua esperança de vida é diminuída por causa de apoptose ou por ação citotóxica dos linfócitos CTL. Portanto, o acréscimo no termo de morte é devido aos efeitos apoptóticos e a ação do CTL ocorre de forma linearmente dependente da quantidade de células infectadas apresentando fragmentos do invasor em seus MHC I.

Similarmente aos macrófagos, as células dendríticas transportam os fragmentos das partículas virais aos órgãos linfáticos, conforme mencionado no item I.2. Uma vez iniciado o processo de reconhecimento, as células dendríticas proliferam com uma taxa $\varsigma_{2}$ de acordo com o nível da resposta imune (Equação 3). Assim como os macrófagos ativos, as células dendríticas também nascem com um fluxo $s_{i d}$ e morrem por causa natural em uma taxa $\mu_{i d}$. 
Quadro 2: Descrição e referência das variáveis de estado existentes

\begin{tabular}{|c|c|c|}
\hline Variável & Descrição & Referência \\
\hline$M f$ & $\begin{array}{l}\text { Macrófagos, já ativos, que entram em contato com vírus HIV-1 para } \\
\text { combatê-los. }\end{array}$ & $\begin{array}{l}\text { De Boer et al. (1985); De Boer, Hogeweg (1986); } \\
\text { Bou-Habib, DC (Com. Pes.) }\end{array}$ \\
\hline$M f i$ & $\begin{array}{l}\text { Macrófagos que são infectados pelo contato viral e permanecem ainda } \\
\text { ativos, embora contenham partículas virais em seu interior em } \\
\text { replicação. Posteriormente, passam pelo processo de apresentação de } \\
\text { antígenos. }\end{array}$ & $\begin{array}{l}\text { Coleman, R. et al. (1989); Gorry, PR et al. (2005); } \\
\text { Aquaro,S et al. (2002); Schrier, McCutchan, Wiley } \\
\text { (1993) }\end{array}$ \\
\hline$i D C$ & $\begin{array}{l}\text { Células dendríticas imaturas que, após migração, encontram } \\
\text { fragmentos virais (ou mesmo vírions inteiros) para posterior } \\
\text { apresentação de antígenos ao linfonodo. }\end{array}$ & Vanham, G et al. (2000); Wu,KemalRamani (2006). \\
\hline$m D C$ & $\begin{array}{l}\text { Células dendríticas já amadurecidas pelo processo de apresentação de } \\
\text { antígenos e que carregam vírions em suas proteínas DC-SIGN em } \\
\text { direção ao linfonodo. }\end{array}$ & $\begin{array}{l}\text { Hlavacek, WS et al. (2002;1999); } \\
\text { Moris, A et al. (2006). }\end{array}$ \\
\hline T4 & $\begin{array}{l}\text { Linfócitos } \mathrm{TCD}^{+} \text {que são formados após o contato com as células } \\
\text { apresentadoras de antígenos (macrófagos e células dendríticas). }\end{array}$ & Fauci, AS et al. (1996); Fraser, C et al. (2002). \\
\hline$T 4 i$ & $\begin{array}{l}\text { Linfócitos } \mathrm{TCD}^{+} \text {que são infectados oriundos do contato com células } \\
\text { apresentadoras de antígenos contendo vírions. }\end{array}$ & Haase, AT (1999); Smith, PD et al. (2000) \\
\hline T4lat & $\begin{array}{l}\text { Linfócitos } \mathrm{TCD}^{+} \text {que são latentemente infectados pelo contato com } \\
\text { células apresentadoras de antígeno contendo vírions. }\end{array}$ & $\begin{array}{l}\text { Müller, Vigueras-Gómez, Bonhoeffer (2002); } \\
\text { Essunger, Perelson (1994). }\end{array}$ \\
\hline$C T L$ & $\begin{array}{l}\text { Linfócitos TCD8+ que são produzidos pelo contato com linfócitos } \\
\text { TCD }^{+} \text {ativos e policlonados. }\end{array}$ & Rouzine, Sergeev, Glushtsov (2006). \\
\hline$v$ & Carga viral & Perelson, A S (2002); Perelson, Nelson (1999). \\
\hline
\end{tabular}


Após o contato com os fragmentos - e com os vírions ainda completos -, estes se ligam com uma probabilidade $\mathrm{K}_{1}$ à membrana celular nos receptores SIGN. Esta taxa de infecção segue uma função de saturação (Holling tipo II) na forma de $v /\left(v+\kappa_{v}\right)$, sendo $\kappa_{v}$ a constante de saturação que corresponde à metade da capacidade máxima de partículas virais presas aos receptores (Equação 4). Tais células entram em processo de diferenciação, deixam o compartimento de células imaturas e são conduzidas pelos canais linfáticos até os órgãos linfóides para o processo de apresentação de antígenos. Durante este processo de transformação e transporte, as células dendríticas passam ao caráter de células infectadas $(m D C)$, realizando a chamada "sinapse infecciosa" (STEBBING, BOWER 2006; WU, KEWALRAMANI 2006) com os linfócitos TCD4 ${ }^{+}$. O número de contato que realizam, semelhantemente aos macrófagos, é de $\beta_{d c} m D C$, onde $\beta_{\mathrm{dc}}$ traduz a quantidade e a forma do contato que uma célula dendrítica realiza com um linfócito. Então, sua contribuição para a variação dos linfócitos $\mathrm{TCD}^{+}$é $\beta_{d c} m D C * T 4$. Uma vez que este contato tenha sido efetivo, a célula dendrítica morre por causas naturais (sua esperança de vida é menor do que no estado imaturo) ou por ação dos linfócitos CTL que se dá através da identificação do invasor na apresentação do antígeno presente nos MHC I. O processo de apresentação de antígeno, conforme mostrado nos parágrafos anteriores, conduz a resposta imune adaptativa, um conjunto de reações que resultam em aumento de células efetoras, citotóxicas e de memória.

Durante o processo de apresentação, seja por macrófagos ou células dendríticas, admitese que a eficiência da infecção nos linfócitos é guiada por alguns fatores, como a integridade viral, transfecção efetiva e acoplamento das duas populações. Para os macrófagos ativos e ativos infectados, esta "transferência" viral pode ocorrer intra ou extra órgão linfóide, principalmente nos sítios de inflamação. Porcheray et al. (2006), observando alguns dados, analisa a possibilidade do HIV atuar em processos antes e depois da inflamação, no tocante a capacidade infecciosa. No modelo, estas características podem ser traduzidas pela expressão $a \xi^{*}(1-\exp (-$ $\gamma t)) / \gamma$, onde a parcela $\xi$ relaciona as duas populações envolvidas, macrófagos infectados e linfócitos TCD4 ${ }^{+}$naïves.

No caso das células dendríticas, a infecção ocorre dentro dos órgãos linfóides e a transfecção pode ocorrer de forma simples ou cruzada. A primeira privilegia a transferência de 
partículas virais (acopladas nas moléculas SIGN) aos linfócitos TCD4 $^{+}$naïves e para a apresentação cruzada, Marañon et al. (2004) teoriza que pode haver contato entre TCD4 ${ }^{+}$naïves e complexos formados por células dendríticas e $\mathrm{TCD}^{+}$infectados. Semelhantemente aos macrófagos infectados, a expressão que formaliza este contato é mostrada como a eficácia do contato e a relação entre as duas concentrações, $a \varphi^{*}(1-\exp (-\gamma t)) / \gamma$.

No processo de diferenciação celular pelo qual o linfócito $\mathrm{TCD}^{+}$passa no momento da proliferação celular, uma parte retém um fenótipo "de memória", permanecendo assim até que sejam ativadas por algum mecanismo (ainda desconhecido) e realizem seu papel na resposta imunológica.A fração que se torna efetora cresce com um fluxo constate $s_{4}$ e morre por causas naturais a uma taxa $\mu$, além de ser estimulado a proliferar após a sinalização antigênica, proporcional às concentrações de macrófagos infectados e células dendríticas contendo vírus. Entretanto, como foi dito anteriormente, este processo tem a capacidade de formar linfócitos $\mathrm{TCD}^{+}$infectados, divididos em duas subpopulações: os produtivamente $(T 4 i)$ e os cronicamente infectados (T4lat).

Para a primeira subpopulação, o início da síntese viral acontece após um período de latência $\tau$, determinando pelos mecanismos de entrada, inserção e estabilização do DNA viral no material genético do hospedeiro. Uma vez que esta infecção acontece quando a célula está ativada, após este período de latência há o aumento desta população, que sobrevive segundo uma esperança de vida menor que aquela do linfócito não infectado, devido aos efeitos citolíticos do ciclo viral (CIUPE et al., 2006) ou à resposta imunológica na forma do linfócito CTL. Esta população de células produtivamente infectadas possuem uma probabilidade de sobrevivência (segundo uma distribuição exponencial) intimamente relacionada à latência $\tau$, depois do qual a resposta imunológica começa a atuar sobre eles. O total de vírus formado $\left(Q_{1} *\left(\mu+\alpha^{*}\right)\right)$ depende não só da quantidade viral interna à célula - $Q_{1^{-}}$, mas também da concentração celular - $(\mu+$ $\left.\alpha^{*}\right) * T 4 i$-, onde $1 /\left(\mu+\alpha^{*}\right)$ é a esperança de vida celular deste linfócito infectado, menor do que a célula não infectada.

No caso da população cronicamente infectada, o raciocínio é semelhante, pois a célula

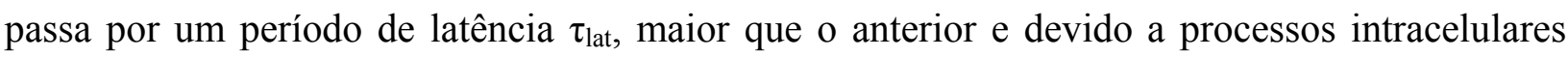
ainda pouco compreendidos, fazendo com que o Sistema Imune não enxergue como ameaça e não seja destruída pelos CTL. Permanece como um dos principais reservatórios de síntese e 
proliferação virais. Com o avanço da infestação e infecção (também com microrganismos oportunistas), estes linfócitos TCD4+ cronicamente infectados são revertidos ao estado de ativação, após o período de latência $\tau_{\text {lat }}$, tornam-se produtivamente ativadas com uma taxa proporcional à 0,005 cell $(\mu 1 . d i a)^{-1}$, produzindo partículas virais em uma quantidade $\mathrm{Q}_{2} \mathrm{e}$ proporcional à concentração de células $\left(\mu+\alpha_{\text {lat }}{ }^{*}{ }^{*} *\right.$ T4lat, onde $1 /\left(\mu+\alpha_{\text {lat }}{ }^{*}\right)$ é a esperança de vida das células latentemente infectadas. Estas células são geralmente ativadas em sítios de inflamação ou na existência de infecções recorrentes.

Sabe-se que, simultaneamente à ativação e subseqüente proliferação dos linfócitos $\mathrm{TCD} 4^{+}$, são ativados também os linfócitos $\mathrm{TCD} 8^{+}$, que reconhecem as demais células infectadas por meio dos complexos MHC classe I, conforme comentado no capítulo de Introdução.

Os linfócitos CTL crescem linearmente com um fluxo $s_{8}$ e morrem de causas naturais. O controle da infecção exercido pelo Sistema Imune faz com que a concentração de CTL aumente de acordo com dois possíveis mecanismos, comentados no item I.5 do capítulo de Introdução, devido ao processo de apresentação de antígenos. Neste modelo, o reconhecimento dos antígenos invasores e subseqüente ativação aparece no último termo da equação da variação do compartimento de CTL e é linearmente dependente de $\mathrm{TCD}^{+}{ }^{+}$e macrófagos infectados e células dendríticas contendo vírus, à uma taxa $\psi$, característica para cada tipo de acoplamento e apoptose gerada. Embora os mecanismos de erradicação celular não estejam completamente conhecidos, verifica-se na literatura uma grande variação de possibilidades matemáticas que simbolizam o efeito citotóxico do linfócito TCD8 ${ }^{+}$(ASQUITH et al., 2006; ROUZINE, SERGEEV, GLUSHTSOV; 2006). Dos trabalhos de De Pillis, Radunskaya, Wiseman (2005) e De Pillis, Radunskaya (2003), verifica-se o uso de uma expressão relacionando duas populações envolvidas sob a forma de um funcional tipo II (ou de saturação) representando possíveis mecanismos envolvidos no reconhecimento e destruição de células tumorais. Entretanto, no presente trabalho se fez uso da Lei de Ação das Massas por ser mais simples na representação das populações envolvidas no controle e erradicação da infecção viral. 


\subsection{Simulação do Modelo}

Quando uma doença ou uma infecção é introduzida em uma dada população, após um determinado período de tempo pode-se verificar estados transientes e de equilíbrio, denominado equilíbrio endêmico, onde se vê um número constante de "indivíduos" infectados por unidade de tempo. O conhecimento melhor da dinâmica que esta doença exerce sobre os indivíduos e/ou sobre a população, realiza-se simulações baseadas em determinados parâmetros ou taxas proporcionais aos fluxos de passagem de um compartimento a outro.

Tais simulações são efetuadas por procedimento de integração das equações diferencias que compõe o modelo e seus valores são então plotados em um gráfico, a cada instante ou passo de integração, com a finalidade de observação da cinética de mudança dos respectivos valores. Neste trabalho foi usado o software Berkeley Madonna 8.0.1 ${ }^{\circledR}$ para simular o conjunto de equações (MACEY, OSTER, ZAHNLEY; 2000) com o algoritmo de integração de Runge-Kutta de $4^{\mathrm{a}}$ ordem, com tamanho do passo de integração de 0,005 . Os dados que entraram como parâmetros nas funções e valores iniciais foram obtidos diretamente da literatura, conforme indicado na Tabela 1.

Elegeu-se em cada compartimento apropriado, as variações características do Sistema Imune diante da infecção (em base teórica), existente em um paciente sem qualquer tratamento. A escolha desta abordagem se deve à necessidade de um conhecimento melhor dos mecanismos imunológicos em seus diferentes estados de ativação.

A "força de infecção", relacionada à presença do HIV na apresentação de antígenos e ativação dos linfócitos $\mathrm{TCD}^{+}$por macrófagos infectados e células dendríticas contendo partículas virais, expõem o fato que a população mais importante para a manutenção da infecção de linfócitos é o dos macrófagos infectados, pelo processo de ativação e apresentação de antígenos. A apresentação pelo pool de células dendríticas não aparece, o que poderia ser explicado pelo fato de que tais células sofrem apoptose após a sinapse com os TCD4+, não sobrevivendo para continuação da proliferação viral. Os CTL ativados sofrem diretamente os efeitos de morte celular induzida pelo processo de apresentação de antígeno, levando ao declínio da concentração no paciente. Em consideração ao delay representando o intervalo de tempo para que o ciclo viral se complete no ambiente intracelular, este foi considerado somente nas sub- 
populações de $\mathrm{TCD} 4^{+}$produtivamente e cronicamente infectados para quantificar a expansão destes dois subconjuntos celulares.

A expressão que traduz a instalação e proliferação da infecção, denominada Número de Reprodutibidade Basal (capítulo de Modelos Matemáticos), foi calculada de acordo com o apresentado em Burattini et al. (1998). A presença do autovalor $\lambda$ na expressão final obtida conduz ao uso do teorema de El'sgol'ts, onde se assegura que se todas as soluções de $\lambda$ forem negativas então o sistema caminha assintoticamente para a estabilidade. Logo, o resultado seguinte é valido tanto para sistemas com delay (EL’SGOL’TS (1966) apud BURATTINI; 1998) como sem delay. Segue abaixo a expressão para o $R_{0}$ :

$$
\begin{aligned}
& \mathrm{R}_{0}(t)=\frac{(1-z) * \operatorname{tax} * \xi *\left(\frac{1-e^{-\gamma t}}{\gamma}\right) \cdot \exp -\left(\mu+\alpha_{l a t}^{*}\right) \tau_{l a t}}{\left(\mu+\alpha_{l a t}^{*}\right)+0,005} \\
& \text { factor_CTL }=\frac{\psi_{1}^{c t l}-\xi^{\prime}}{\psi_{3}^{c t l}} \\
& \mathrm{R}_{0}^{\mathrm{tot}}(t)=\frac{(1-z)^{*} \operatorname{tax} * \xi^{*}\left(\frac{1-e^{-\gamma t}}{\gamma}\right) \cdot e^{-\left(\mu+\alpha_{l a t}^{*}\right) \tau_{l a t}}}{\left(\mu+\alpha_{l a t}^{*}\right)+0,005} \frac{\psi_{1}^{c t l}-\xi^{\prime}}{\psi_{3}^{c t l}} e^{-\lambda \tau_{l a t}}
\end{aligned}
$$

A expressão de $\mathrm{R}_{0}{ }^{\text {tot }}(\mathrm{t})$ possui um termo como função do tipo de atraso e do autovalor $\lambda$. Assumindo o teorema de El'sgol'ts, o termo exponencial $\mathrm{e}^{-\lambda \tau}$ pode ser considerado unitário. A matriz abaixo contém os termos que causam as variações ou perturbações no conjunto de equações descrito anteriormente:

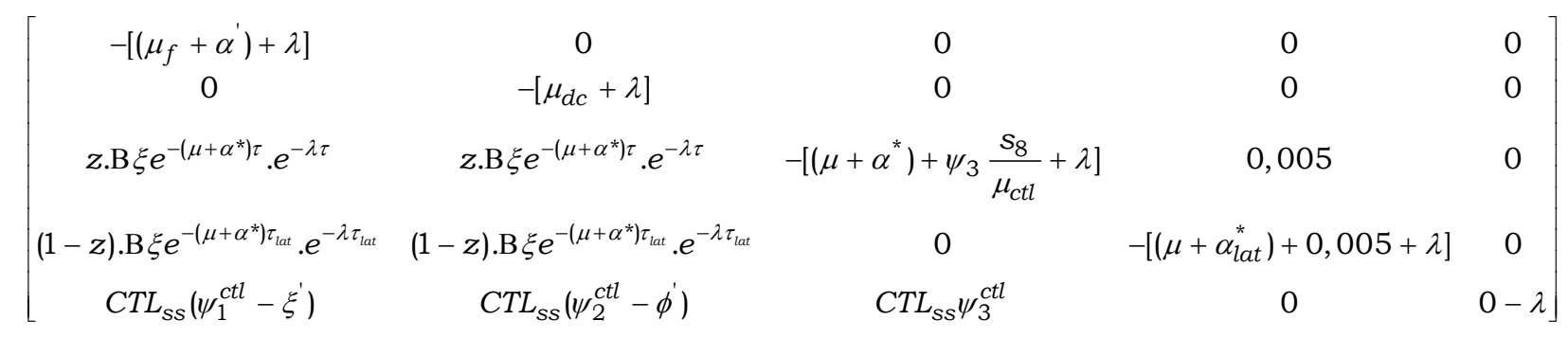

\footnotetext{
${ }^{7}$ El'sgol'ts, E L Introduction to the theory of Differential Equations with deviating arguments. Holden-day Inc., San Franscisco, 1966.
} 
Interessantemente, o valor obtido em $\mathrm{R}_{0}{ }^{\text {tot }}$ é menor que 1 , sem ainda empreender o uso da expressão relativa aos CTL. Tal resultado pode parecer incoerente, todavia, se for lembrado o fato que a infecção se inicia pela maneira natural de contato, uma vez que o agente infectante destrua seu "alvo" celular, não terá como proliferar. Portanto, a infecção findará. Entretanto, globalmente ela se mantém devido ao fato de estar sempre iniciando devido ao processo de apresentação e reconhecimentos dos fragmentos protéicos do invasor realizado por macrófagos e células dendríticas infectados. Vários ciclos de infecção e morte podem estar presentes na dinâmica da patogênese do HIV.

Como o conjunto de células dendríticas parece contribuir de forma ainda não muito bem compreendida, o sistema é conduzido, provavelmente, à um equilíbrio entre as populações celulares mencionadas anteriormente e o agente infectante, neste caso, o HIV-1. Tal equilíbrio pode ser modificado em prol da ação viral quando proteínas pertencentes ao genoma do HIV interfere em mecanismos bioquímicos de seus hospedeiros, como é o caso das proteínas Nef, Vpr, Tat e Vif, cada uma interferindo ou em processos de sinalização ou em ativação e anergia, ou apoptose.

As expressões matemáticas que revelam o equilíbrio que o Sistema assume com os parâmetros adotados são mostradas nas Equações 13 a 15. Neste conjunto, verifica-se o estado estacionário para macrófagos infectados, células dendríticas maduras contendo vírus e linfócitos $\mathrm{TCD}^{+}$infectados produtivamente. O Jacobiano encontra-se no Anexo I. A importância da transfecção pelos macrófagos infectados e células dendríticas no processo de apresentação de antígenos virais pode ser vista na equação que representa os linfócitos TCD4+ infectados (Equação 15).

$$
\begin{aligned}
M f i_{e q} & =\frac{\beta_{1}}{\left(\mu_{f}+\alpha^{\prime}\right)+\beta_{m f} \frac{s_{4}}{\mu}+\psi_{1} \frac{s_{8}}{\mu_{c t l}}} \cdot M f_{s s} \\
m D C_{e q} & =\frac{K_{1}}{\mu_{d c}+\beta_{d c} \frac{s_{4}}{\mu}+\psi_{2} \frac{s_{8}}{\mu_{c t l}}} \cdot i D C_{s s} \\
T 4 i_{e q} & =\left(\psi_{3}^{c t l}\right)^{-1} \cdot\left[\mu_{c t l}+\left(\xi^{\prime}-\psi_{1}^{c t l}\right) \cdot M f i_{e q}+\left(\phi^{\prime}-\psi_{2}^{c t l}\right) \cdot m D C_{e q}\right]
\end{aligned}
$$




\section{Resultados e Discussões}

Antes de iniciar a discussão e análise dos resultados, gostaria de proporcionar algumas observações sobre Crescimento das Populações.

Para se escolher um determinado tipo de modelo, não há justificativa real para assumir esta ou aquela representação matemática como a ideal. Na verdade, é mais uma questão da escolha do pesquisador responsável que, para tanto, usa coerentemente três classes de modelos, comentados abaixo:

- Classe 1: A população estudada cresceria indefinidamente caso não houvesse o controle exercido pelas mortes naturais. A população alcançaria valores infinitamente grandes, semelhantes a uma explosão demográfica. Como nos demais equacionamentos, $s_{I}$ representa o crescimento e $\mu$ a taxa de morte populacional.

$$
\frac{d T 4}{d t}=s_{1}-\mu T 4 \quad, \operatorname{com} \frac{d T 4}{d t}=0 \Rightarrow T 4=\frac{s_{1}}{\mu}
$$

Esse valor obtido acima corresponde ao Equilíbrio Demográfico que a população hipotética X sob estudo pode alcançar.

- Classe 2: Neste caso, a população cresce até um determinado limite de suporte, que é característico do meio onde está, e independente das mortes naturais. Tais limites podem ser devidos ou às áreas geográficas ou competição entre populações (ou espécies).

$$
\frac{d X}{d t}=s_{1}\left(1-\frac{X}{X_{\text {máx }}}\right) X-\mu X \quad, \operatorname{com} \quad \frac{d X}{d t}=0 \Rightarrow X=\frac{s_{1}-\mu}{s_{1}} X_{\max }
$$


Como se vê, a expressão do Equilíbrio Demográfico demonstra a relação entre os indivíduos sobreviventes e a quantidades de indivíduos que nasceram (ou entraram) em um dado período de tempo, relação esta proporcional ao tamanho máximo desta população.

- Classe 3: A terceira possibilidade, que é a mais simples, se faz quando se supõe que a população cresce a uma taxa constante e indefinidamente. Neste caso, somente há Equilíbrio Demográfico quando $s_{1}=\mu$.

Em Epidemiologia, estas considerações são mais práticas quando a maneira conforme a população cresce não é importante, como no caso de um modelo SIR (Suscetível - Infectado Recuperado).

Neste trabalho, a maneira como a população de linfócitos TCD4 ${ }^{+}$cresce é importante, pois afeta a forma e a rapidez da resposta do Sistema Imune. No primeiro Modelo, a população cresce linearmente (lentamente) e morre exponencialmente, na ausência da doença. No caso do segundo Modelo, a mesma população cresce de forma exponencial e morre também exponencialmente, na ausência da doença. Todavia, o crescimento da população é atenuado a uma taxa que diminui com o aumento da população, isto é, a velocidade decai assim que se aproxima de um termo máximo (denominado carrying capacity) característico do sistema sob estudo. No caso do terceiro Modelo, ambas as populações crescem exponencialmente e na mesma velocidade, quando não há presença de doenças. Como a análise é realizada a partir do instante de tempo onde se verifica o equilíbrio entre "entrada" e "saída" de indivíduos, diz-se que os fenômenos de crescimento e morte não são importantes para a representação (simulações) do que acontece com a população sob estudo no caso de infecções. É um caso particular do primeiro Modelo.

Considerando os compartimentos listados no Quadro 2, foi obtida uma boa representação da dinâmica do Sistema Imune na situação de infecção de um indivíduo infectado pelo vírus HIV-1 e tratamento com drogas anti-retrovirais. Na Tabela 1 são listados os parâmetros e respectivos valores utilizados neste trabalho. 
Tabela 1: Valores e Descrição dos Parâmetros Cinéticos do Modelo

\begin{tabular}{|c|c|c|c|}
\hline Variável & Valor & Descrição & Referência \\
\hline$S_{m}$ & 16,3 & $\begin{array}{l}\text { Influxo de macrófagos ativados no } \\
\text { compartimento de macrófagos ativos }\end{array}$ & $\begin{array}{l}\text { de Bôer; Hogewag } \\
\text { (1986) }\end{array}$ \\
\hline$\lambda_{1}$ & 0,002 & $\begin{array}{l}\text { Taxa de crescimento dos macrófagos ativos } \\
\text { dentro do compartimento }\end{array}$ & $\begin{array}{l}\text { de Bôer; Hogewag } \\
\text { (1986) }\end{array}$ \\
\hline$\beta_{1}$ & 0,88 & $\begin{array}{l}\text { Proporção de macrófagos ativos que } \\
\text { encontram as partículas virais e são infectados }\end{array}$ & Estimado \\
\hline$n$ & 0,55 & Coeficiente de Hill & Chaudhry et al. (2004) \\
\hline$K v$ & 100 & Coeficiente de saturação & Estimado \\
\hline$\mu_{f}$ & 0,0285 & $\begin{array}{l}\text { Taxa de morte celular referente aos } \\
\text { macrófagos ativos }\end{array}$ & $\begin{array}{l}\text { de Bôer; Hogewag } \\
\text { (1986) }\end{array}$ \\
\hline$\beta_{m f}$ & $4,5 \times 10^{-4}$ & $\begin{array}{l}\text { Taxa de contato entre os macrófagos } \\
\text { infectados e linfócitos CD4+ no interior dos } \\
\text { linfonodos }\end{array}$ & Vaham G et al. (2000) \\
\hline$\alpha$ & 0,02 & $\begin{array}{l}\text { Acréscimo no termo de morte dos macrófagos } \\
\text { infectados }\end{array}$ & Estimado \\
\hline$S_{i d c}$ & 37,6 & $\begin{array}{l}\text { Influxo de células dendríticas ainda imaturas } \\
\text { no compartimento de células dendríticas }\end{array}$ & $\begin{array}{l}\text { Mohri et al. (2001) } \\
\text { Moore; Gu (2005) }\end{array}$ \\
\hline$\lambda_{2}$ & 0,085 & $\begin{array}{l}\text { Taxa de crescimento celular referente às } \\
\text { células dendríticas }\end{array}$ & $\begin{array}{l}\text { Rouzine; Murali- } \\
\text { Krishna; Ahmed } \\
\text { (2005) }\end{array}$ \\
\hline$K_{1}$ & 80 & $\begin{array}{l}\text { Proporção de células dendríticas ainda } \\
\text { imaturas que encontram fragmentos e/ou } \\
\text { partículas virais }\end{array}$ & $\begin{array}{l}\text { Rouzine; Murali- } \\
\text { Krishna; Ahmed } \\
(2005)\end{array}$ \\
\hline$\kappa_{v}$ & 4,5 & $\begin{array}{l}\text { Constante de saturação para ligação célula } \\
\text { dendrítica - HIV }\end{array}$ & Estimado \\
\hline$\mu_{i d}$ & 0,005 & Taxa de morte das células dendríticas imaturas & Vaham G et al. (2000) \\
\hline$\beta_{d c}$ & $\begin{array}{c}4,171 \mathrm{x} \\
10^{-3}\end{array}$ & $\begin{array}{l}\text { Taxa de contato entre células dendríticas e } \\
\text { linfócitos } \mathrm{CD} 4+\text { no interior dos linfonodos. }\end{array}$ & $\begin{array}{l}\text { Moris A et al. (2006) } \\
\text { Hlavacek; Stilianakis; } \\
\text { Perelson (2000) }\end{array}$ \\
\hline$\mu_{d c}$ & 0,025 & Taxa de morte das células dendríticas maduras & Estimado \\
\hline
\end{tabular}




\begin{tabular}{|c|c|c|c|}
\hline & & e infectadas & \\
\hline$s_{4}$ & 0,025 & $\begin{array}{l}\text { Influxo de linfócitos TCD4+ no } \\
\text { compartimento de ativação e proliferação }\end{array}$ & $\begin{array}{l}\text { Moore; Gu (2005) } \\
\text { Mohri H et al. (2001) }\end{array}$ \\
\hline$a$ & 0,93 & $\begin{array}{l}\text { Proporção de contatos entre linfócitos TCD4+ } \\
\text { ativos e células contendo infecção viral }\end{array}$ & Estimado \\
\hline$\mu$ & 0,015 & Taxa de morte dos linfócitos TCD4+ ativos & Jones; Perelson (2005) \\
\hline$z$ & 0,90 & $\begin{array}{l}\text { Fração de linfócitos que estão produtivamente } \\
\text { infectados }\end{array}$ & Estimado \\
\hline$\tau$ & 0,13 & $\begin{array}{l}\text { Atraso entre a infecção e a produção dos } \\
\text { vírions no interior dos linfócitos TCD4+ }\end{array}$ & Dixit; Perelson (2004) \\
\hline$\alpha^{*}$ & 0,332 & $\begin{array}{l}\text { Acréscimo no termo de morte dos linfócitos } \\
\text { produtivamente infectados }\end{array}$ & $\begin{array}{l}\text { Dixit; Perelson (2004) } \\
\text { Moore; Gu (2005) }\end{array}$ \\
\hline$\tau_{\text {lat }}$ & 20 & $\begin{array}{l}\text { Atraso entre a infecção e a produção viral para } \\
\text { linfócitos latentemente infectados }\end{array}$ & Estimado \\
\hline$\alpha^{*}{ }_{l a t}$ & 0,132 & $\begin{array}{l}\text { Acréscimo ao termo de morte celular para os } \\
\text { linfócitos TCD4+ para os latentemente } \\
\text { infectados }\end{array}$ & Jones; Perelson (2005) \\
\hline$s_{8}$ & 0,0023 & $\begin{array}{l}\text { Influxo de linfócitos TCD8+ no } \\
\text { compartimento de proliferação }\end{array}$ & Moore; Gu (2005) \\
\hline$\mu_{c t l}$ & 0,136 & Taxa de morte dos linfócitos TCD8+ & Estimado \\
\hline$\Psi_{1}$ & $1,5 \times 10^{-3}$ & $\begin{array}{l}\text { Taxa de contato entre Macrófagos infectados e } \\
\text { CTL efetor }\end{array}$ & Asquith B et al. (2006) \\
\hline$\Psi_{2}$ & $2,0 \times 10^{-4}$ & $\begin{array}{l}\text { Taxa de contato entre Células Dendríticas } \\
\text { contendo vírus e CTL efetor }\end{array}$ & Asquith B et al. (2006) \\
\hline$\Psi_{3}$ & $2,5 \times 10^{-4}$ & $\begin{array}{l}\text { Taxa de contato entre linfócitos TCD4 }{ }^{+} \\
\text {infectados e CTL efetor }\end{array}$ & Asquith B et al. (2006) \\
\hline$Q_{1}$ & 750 & $\begin{array}{l}\text { Número de vírions formados pela infecção e } \\
\text { morte dos linfócitos TCD4+ ativos }\end{array}$ & Jones; Perelson (2005) \\
\hline$Q_{2}$ & 80 & $\begin{array}{l}\text { Número de vírions formados pela infecção e } \\
\text { morte dos linfócitos TCD4+ latentemente } \\
\text { infectados }\end{array}$ & Jones; Perelson (2006) \\
\hline$Q_{3}$ & 250 & $\begin{array}{l}\text { Número de vírions formados pela infecção e } \\
\text { morte macrófagos infectados }\end{array}$ & $\begin{array}{l}\text { Perelson; Nelson } \\
\text { (1999) }\end{array}$ \\
\hline
\end{tabular}




\begin{tabular}{llll}
\hline$\psi$ & $\begin{array}{l}8,62 \mathrm{x} \\
10^{-5}\end{array}$ & $\begin{array}{l}\text { Taxa de ativação do CTL relativo à } \\
\text { apresentação de antígenos por macrófagos }\end{array}$ & Estimado \\
\hline$\varphi$ & $2,8 \times 10^{-3}$ & $\begin{array}{l}\text { Taxa de ativação dos CTL relativa à } \\
\text { apresentação de antígenos por cel dendríticas }\end{array}$ & Estimado \\
\hline$\Psi^{\prime}$ & $4,8 \times 10^{-4}$ & $\begin{array}{l}\text { Taxa de "morte" dos CTL provocada por } \\
\text { ativação por macrófagos }\end{array}$ & Estimado \\
\hline$\varphi^{\prime}$ & $2,1 \times 10^{-2}$ & $\begin{array}{l}\text { Taxa de "morte" dos CTL provocada por } \\
\text { ativação por células dendríticas }\end{array}$ & Estimado \\
\hline$\Psi_{1}^{c t l}$ & $1,5 \times 10^{-3}$ & $\begin{array}{l}\text { Crescimento dos CTL devido à resposta } \\
\text { imunológica dos Macrófagos infectados }\end{array}$ & Estimado \\
\hline$\Psi_{2}^{c t l}$ & $1,5 \times 10^{-4}$ & $\begin{array}{l}\text { Crescimento dos CTL devido a resposta } \\
\text { imunológica das células dendriticas maduras }\end{array}$ & Estimado \\
\hline$\Psi_{3}^{c t l}$ & 6,1755 & $\begin{array}{l}\text { Crescimento dos CTL devido à resposta } \\
\text { imunológica dos TCD4 }{ }^{+} \text {infectados }\end{array}$ & Estimado \\
\hline$\gamma$ & 2,3 & Velocidade de clearance viral & Perelson, Nelson \\
& & & $(1999)$ \\
\hline
\end{tabular}

Nas simulações, verifica-se a presença das três etapas (ou fases) decorrentes da infecção viral: inicial, assintomática ou crônica e aguda ou AIDS. Nestas, alguns padrões podem ser verificados, como a perturbação do equilíbrio inicial em decorrência do inicio do ciclo viral e instalação da infecção (bem como a ação do Sistema Imune em combatê-la), a fase crônica ou assintomática, onde há um quase-estado estacionário de todos os compartimentos celulares, representando a tendência de sobrevivência do vírus (e seu posterior alastramento) e a fase final, onde praticamente o Sistema Imune sucumbe à proliferação viral. Nota-se, também, que a presença de células de linfócitos CTL não é suficiente para erradicar a continuidade do ciclo viral e muito menos a propagação da infecção, ou devido aos mecanismos de escape do vírus ou à desarticulação da malha sinalizadora da resposta imunológica (Figuras 11a-f).

Uma vez que a infecção se inicia, os linfócitos CTL são empregados para supressão total desta. Segundo Rouzine, Sergeev, Glushtsov (2006), podem co-existir dois mecanismos de 
controle da proliferação do HIV, ambos relacionados com o teor da carga viral. Quando esta apresenta estados estacionários com valores baixos, o controle exercido pelos CTL efetor é dependente da concentração de linfócitos $\mathrm{TCD}^{+}$ativos e não infectados. No outro extremo, quando se verifica um teor de carga viral alto, o mecanismo de controle exercido pelo CTL parece ser independente da presença de linfócitos $\mathrm{TCD}^{+}$e dependente do processo de apresentação de antígeno, conduzindo a população de CTL à morte decorrente de ativação. Tal procedimento de controle pode ser verificado no Modelo e no resultado da simulação (Figura 11f), com a relação $\mathrm{CD}^{+} / \mathrm{CTL}$ permanecendo entre 2,67 e 1,85 , resultado este contrário ao mostrado pelos trabalhos de Fraser et al. (2006).

A ineficiência deste mecanismo pode resultar no fenômeno de Escape Viral (ABBAS, LICHTMAN, POBER; 2003) com a proliferação do HIV aumentando paulatinamente até que a resposta imunológica não seja suficiente para erradicá-lo, sucumbindo e levando o paciente a AIDS. Esse escape viral pode ser decorrência da variabilidade gênica do HIV e também de um reconhecimento de proteínas de membrana pouco efetivo pelos CTL (ASQUITH et al., 2006).

A dinâmica dos linfócitos $\mathrm{TCD}^{+}$, nas simulações (Figuras $11 \mathrm{c}-\mathrm{e}$ ), foi muito próxima dos valores apresentados na literatura. Contudo, diferenças ocorreram no início devido aos delay utilizados no modelo. Isso é bastante interessante do ponto de vista bioquímico, pois considerando os eventos relativos ao ciclo viral e à meia-vida da célula-hospedeiro, este "alongamento temporal" entre o fenômeno de contato e a saía de vírions completos pode ser um processo de adaptação do Sistema Imune ao HIV-1, como discutiremos mais adiante. Na fase inicial da doença ( 0 a 60 dias), encontramos um teor de $\mathrm{TCD}^{+}$infectado em torno de $6 \%$ enquanto no período assintomático (60 a 3000 dias) este teor foi de $8,4 \%$, acima dos valores encontrados na literatura (que é aproximadamente 1\%). Para os linfócitos $\mathrm{TCD} 4^{+}$cronicamente infectados, este teor foi de $2 \%$ na fase inicial (sem delay), $0.11 \%$ (com delay) e de $0,15 \%$ durante a fase assintomática, o que faz acreditar que esta subpopulação de linfócitos infectados possa contribuir muito pouco com a proliferação da dinâmica. Todavia, quando é apreciada a presença do delay, esta subpopulação assume um papel cuja significância não é muito clara, mesmo agindo como um possível reservatório na patogênese do HIV, como comenta o trabalho de Swingler et al. (2003). 

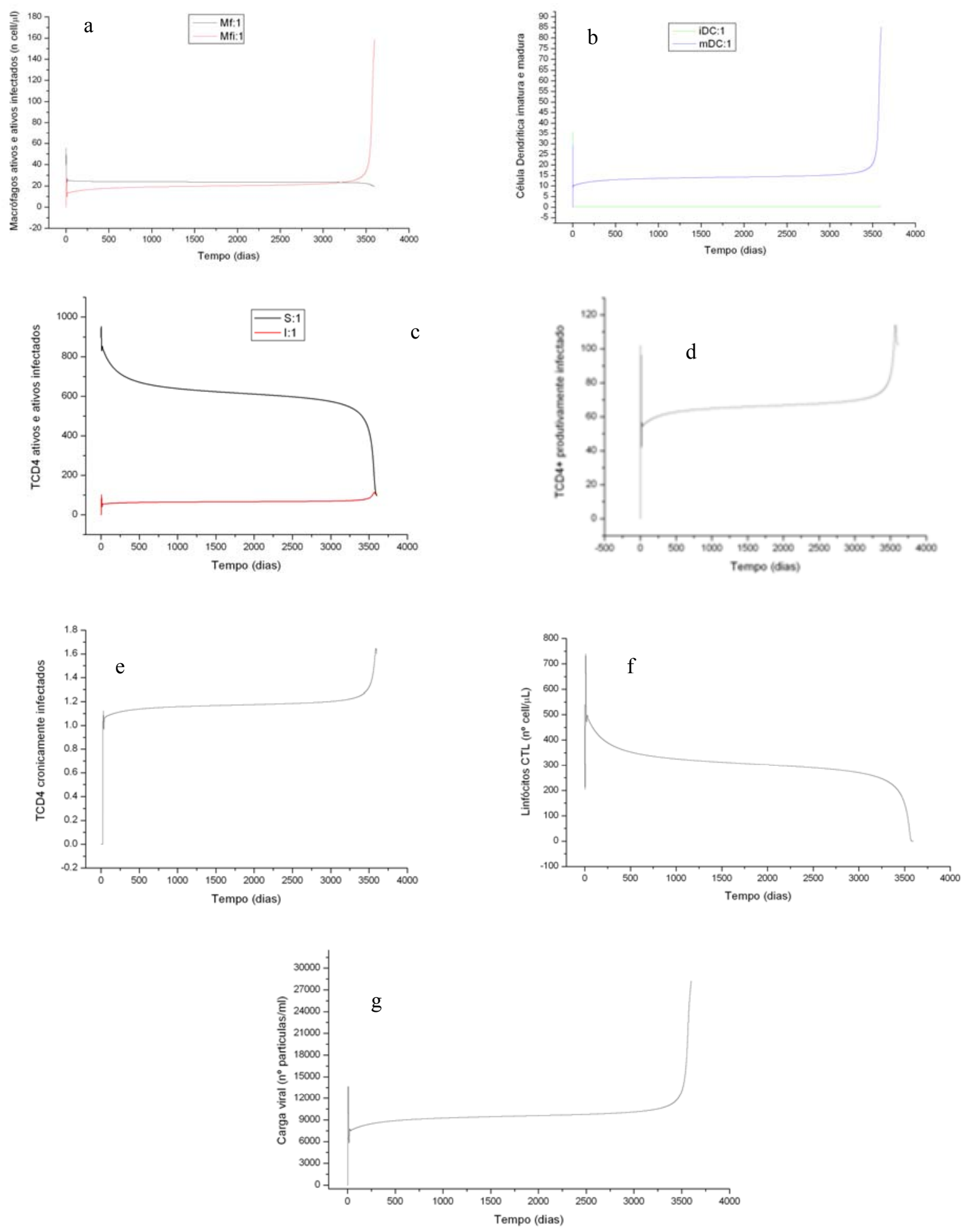

Figura 11: Perfis de variação das concentrações de (a) macrófagos ativos e ativos infectados; (b) Células dendríticas imaturas e maduras (acopladas com vírus); (c) Linfócitos ativos e produtivamente infectados; (d) linfócitos TCD4+ produtivamente infectados; (e) linfócitos TCD4+ cronicamente infectados; (f) linfócitos CTL e (g) carga viral. 
O perfil da cinética de formação dos $\mathrm{TCD}^{+}$infetados e produtivos (Figura 11d) acompanha o perfil citado em literatura e alcança valores entre 55 cell $(\mu 1)^{-1}$ (fase inicial) e 65 cell $(\mu \mathrm{l})^{-1}$ na fase assintomática, mesmo com a continua destruição por ação dos CTL. O fato de existir um delay bioquímico parece não ter grande significância quando se examina mais atentamente o início da cinética de formação desta subpopulação, pois o pico de

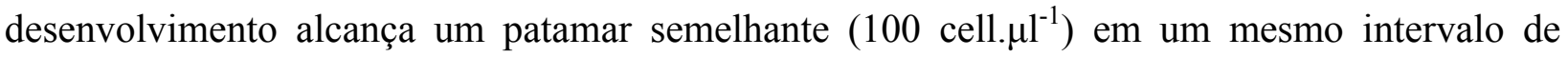
tempo na presença ou ausência de delays. Também não se encontra a inversão da relação de $\mathrm{CD}^{+} / \mathrm{CTL}$ e a taxa de morte dos linfócitos infectados por ação dos CTL é da ordem de 0.0067 , próxima das citadas nos trabalhos de Asquith et al. (2006) e Wick et al. (2005), e a relação de $\mathrm{CD} 4{ }^{+}$infect $/ \mathrm{CTL}$ em torno de $18 \%$, semelhante ao encontrado por Asquith et al. (2006).

O pool de células dendríticas mostra uma cinética semelhante à encontrada nos macrófagos. No momento onde se estabelece a resposta imunológica adaptativa, várias partículas virais encontram-se acopladas aos receptores SIGN para serem notificadas ao linfócito TCD4 ${ }^{+}$ naïve. Nesta fase inicial (entre 0 a 60 dias), praticamente 95,5\% das células dendríticas maturadas encontram-se acopladas a alguma partícula viral e após este período praticamente 100\% deste pool de células está "infectado". Após este período de apresentação de antígenos, é verificado que se estabelece um patamar de equilíbrio cuja concentração de células dendríticas é da ordem de 15 cell $(\mu 1)^{-1}$ (em média). Nos últimos estágios da infecção (final da fase assintomática e posterior estabelecimento da AIDS), há um acúmulo "explosivo" de células, fato também mencionado por Schacker et al. (2000). Analisando os parâmetros cinéticos e simulações, observa-se que a quantidade de vírus absorvida pela célula dendrítica é 80 vírus(cell) ${ }^{-1}$ (Figura 11b), em concordância com os trabalhos de Moris et al. (2006) e Haase, A.T. (1999). Ambos citam valores maiores que este (entre 100 e 180 partículas) enquanto a taxa de encontro entre populações de células dendríticas contendo vírus e linfócitos $\mathrm{TCD} 4^{+}$foi 10 vezes menor que o citado na literatura, variando entre 0,088 (Vanhan et al., 2000) e 0,0109 (Moris et al. 2006). O valor da constante de saturação $\left(\kappa_{v}\right)$ foi obtido por análise dos resultados obtidos pela simulação.

No período inicial da infecção, quando macrófagos ativados encontram partículas virais, a reposta imunológica se dá com um aumento da concentração destes no local de inflamação e uma fração acaba sendo infectada. Através dos resultados das simulações (Figura 11a), 34\% dos macrófagos encontram-se infectados, quase o dobro do valor encontrado por Schrier, 
McCutchain, Wiley (1993) - que foi de 18\% - durante a fase de instalação da patogênese do HIV, chegando a $43 \%$ durante a fase assintomática. Como foi observado na cinética de proliferação das células dendríticas, aqui pode ser visto um período de estado estacionário no crescimento dos macrófagos ativos infectados, com concentração média de 18 cell $(\mu 1)^{-1}$. Com praticamente um terço da população estimada de macrófagos possuindo um caráter infectado e considerando o fato que tais células podem migrar inclusive para os tecidos gliais ou Sistema Nervoso Central, fica evidente a sua importância como um reservatório de proliferação viral e manutenção da infecção. Mecanismos intracelulares e aqueles determinados por citocinas podem favorecer a penetração do vírus no interior do macrófago, utilizando a sua própria função fisiológica com agente de transfecção entre células sadias.

O equilíbrio dos perfis mostrados é modificado pela interferência dos linfócitos CTL nesta dinâmica. Os parâmetros que representam os mecanismos entre macrófagos, macrófagos infectados e CTL são causadores de maior sensibilidade no equilíbrio do sistema, demonstrando o nível de controle exercido em cada compartimento na erradicação da patogênese do HIV, fato não tão pronunciado em relação ao compartimento de células dendríticas. Esta característica reflete o controle exercido pelo Sistema Imune na dinâmica de contenção da infecção e na eficácia da erradicação do corpo do paciente.

Para o caso de variações no valores dos delays $\tau$ e $\tau_{\text {lat }}$ (Figuras 12 e 13), que representam a eficiência de inserção do DNA viral e posterior inicio do ciclo viral, percebe-se que para valores acima de 6 horas (aproximadamente), são formados sub-populações de células produtiva e cronicamente infectadas que são eliminadas ou destruídas mais rapidamente pela resposta imunológica, o que pode ser um indício de uma eficiência maior das células citotóxicas. Provavelmente, isso de dá pelo rápido reconhecimento da sinalização presentes em células infectadas que são reconhecidas pelo CTL. Para que a infecção tivesse curso, em casos de delays altos, dever-se-ia observar que o vírus necessita permanecer mais tempo em contato com a célula (aumento no valor da taxa de contato) e também permanecer em circulação pelo corpo do paciente durante um período de tempo maior que seria mostrado pelo valor de "clearance" viral. Este valor está correlacionado diretamente com o tempo de meia-vida viral. Então, para que exista manutenção da carga viral alta no paciente (excluídos todos os outros fatores), devem-se observar valores menores de "clearance" neste mesmo paciente. 

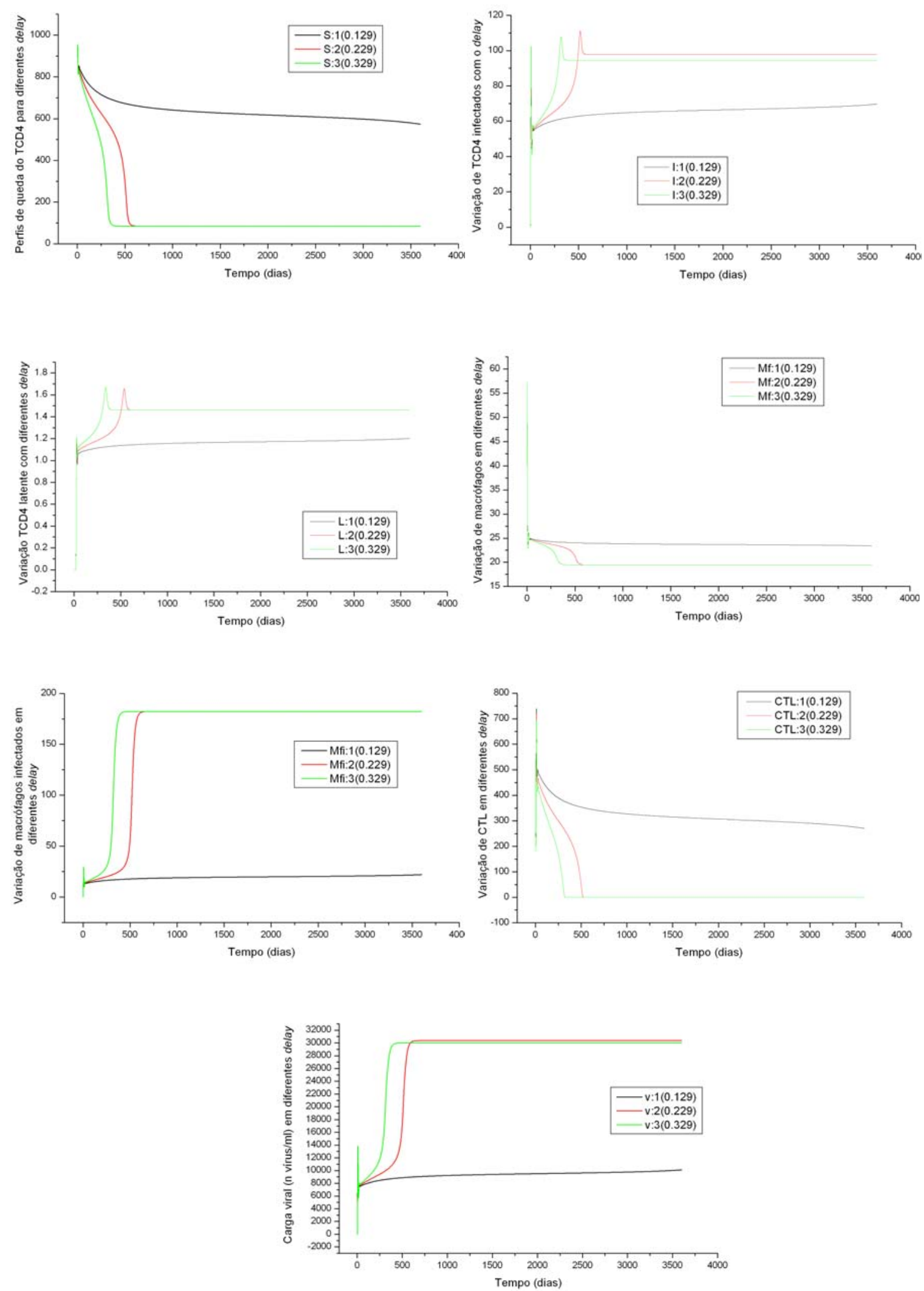

Figura 12: Implicação do uso de diferentes valores para o delay de infecção da cinética dos compartimentos celulares no decorrer da infecção pelo vírus HIV-1. 
Entretanto, a expressão de $R_{O}$ encontrada não é capaz de mostrar se a infecção primária persistirá, contradizendo o que foi verificado nas simulações. Embora tal equação demonstre alguns fatos de interesse, como a propagação via linfócitos $\mathrm{TCD} 4^{+}$cronicamente infectados e o teor do contato dos macrófagos infectados no processo de apresentação de antígenos, os valores utilizados nos parâmetros traduzem a não-instalação da doença, o que é uma incoerência. Isso pode ser decorrente da necessidade da adoção de mais compartimentos para o modelo (aumentando a sua capacidade de representar a dinâmica em si) ou de um procedimento de ajuste aos dados experimentais. Analisando a equação novamente e fazendo uma distinção entre as expressões de $R_{0}$ e $R_{O}{ }^{c t l}$, pode-se demonstrar que $R_{O}{ }^{c t l}<R_{O}<1$, o contrário verificado no trabalho de Asquith et al. (2006).

Há de se ressaltar também, como em Gray et al. (2000), que não há uma homogeneidade de resultados entre os diversos textos científicos, provavelmente devido as diferentes abordagens laboratoriais, a preservação de amostras ou mesmo da grande variabilidade das fontes (pacientes soropositivos) utilizados para estas pesquisas. Outro fato notório é o completo conhecimento dos mecanismos envolvidos na rede celular envolvidos na resposta imune às infecções.
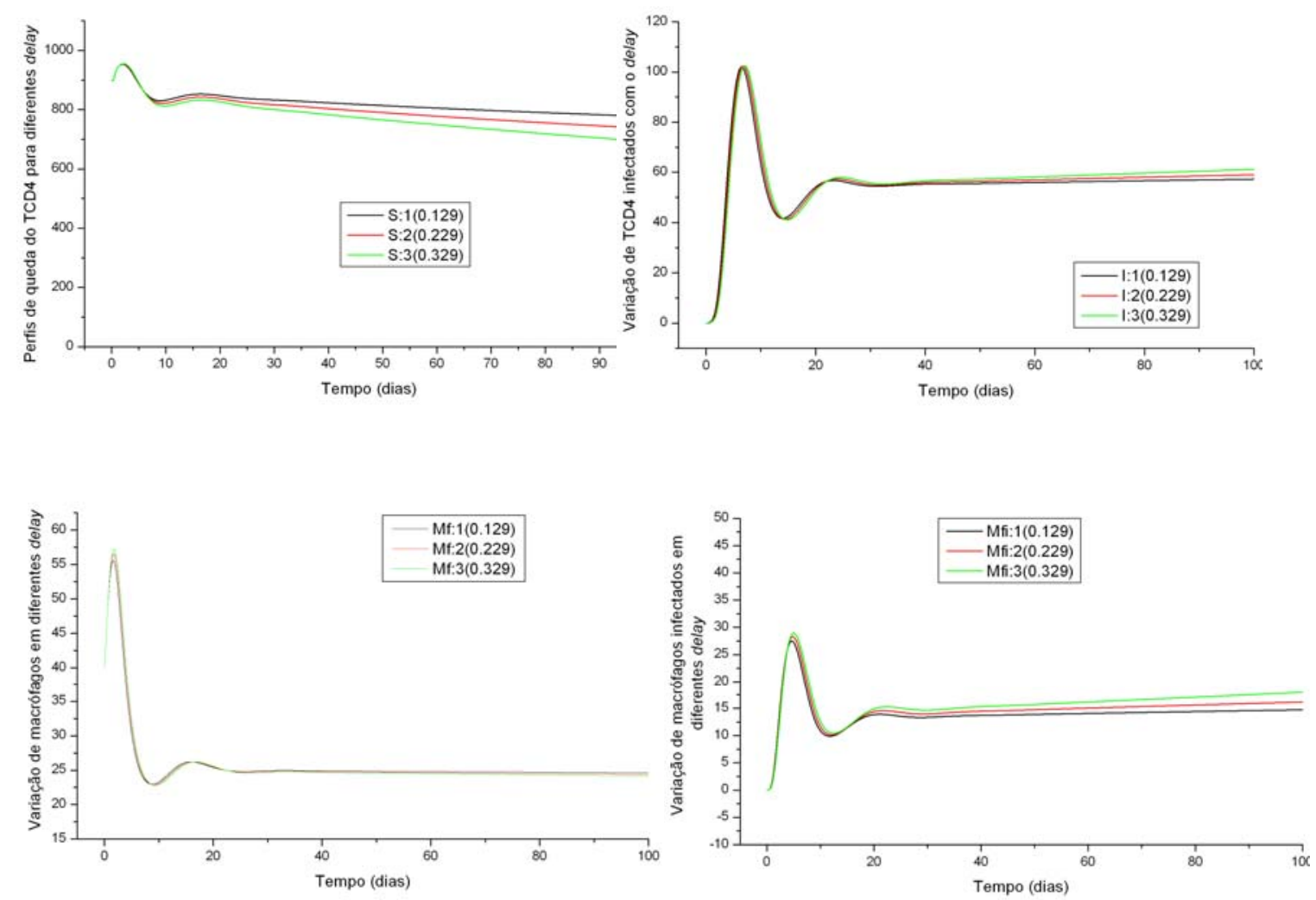

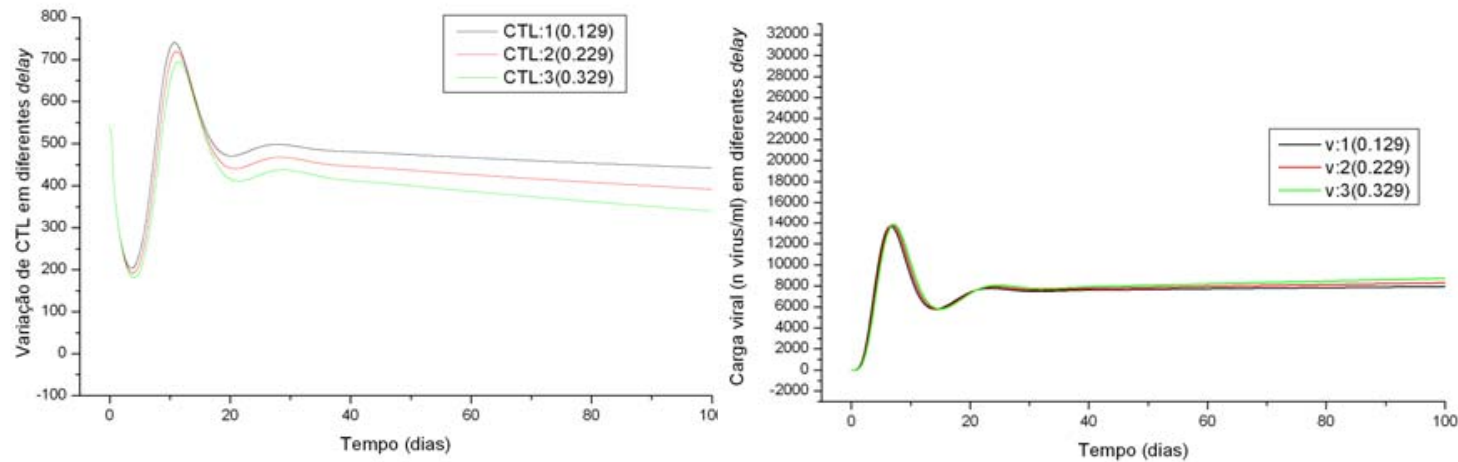

Figura 13: Gráficos relativos aos perfis de variação de macrófagos, linfócitos TCD4+ ativos e produtivamente infectados e linfócitos CTL, bem como da carga viral em três diferentes valores de atrasos (delay) no período inicial da infecção. 


\section{Conclusões}

Com conclusões gerais geradas por este trabalho, pede-se verificar que:

1. Há uma ineficiência do Sistema Imune controlar a proliferação da infecção pelo vírus HIV-1, levando o individuo à AIDS e posteriormente a óbito;

2. Durante a fase do quadro assintomático, a prolongamento do processo imunológico pode levar a uma "dessensibilização" da própria resposta imune devido a "pressão" contínua realizada por células apresentadoras de antígenos (macrófagos infectados e células dendríticas maduras) no interior dos órgãos linfóides, principalmente linfonodos, e posterior queda da quantidade de linfócitos $\mathrm{TCD}^{+}$naïves;

3. Os anticorpos específicos para o HIV diminuem ao longo do tempo de infecção, por causa dos epítopos diferentes. Isso conduz menor eficiência da ação citotóxica dos linfócitos CTL sobre as células infectadas, promovendo o escape viral e a proliferação da infecção propriamente dita;

4. No modelo matemático desenvolvido, a presença do compartimento de células dendríticas mostrou a importância deste conjunto no tocante à apresentação e à implementação da infecção viral nos órgãos linfóides. A constante presença deste pool de células contaminadas (ou infectadas) que exerce uma "pressão" contínua de antígenos tem, como possível efeito, a queda do teor de linfócitos $\mathrm{TCD}^{+}$relacionado ao contínuo recrutamento deste conjunto celular. Contudo, o compartimento de macrófagos foi aquele que mostrou ser o principal causador de manutenção da infecção, após os linfócitos $\mathrm{TCD}^{+}$ativos infectados, prevalecendo como um reservatório viral importante;

5. A representação dos fenômenos bioquímicos relacionados à infecção celular e ao ciclo viral, sob forma de um delay, demonstrou que o efeito de um bloqueio na entrada do vírus à célula traduz em uma maior eficiência no "clearance" viral realizado pela resposta imunológica, o que revela um bom alvo para drogas anti-retrovirais;

6. Existe a necessidade de mais estudos sobre este tema, seja na representação matemática do Sistema Imune (com aumento de compartimentos ou sub-divisão dos já existentes), 
seja no ajuste à dados experimentais para auxiliar na compreensão das interações virais com estes grupos celulares, reconhecimento de novos epítopos e análise de subtipos formadores e não formadores de sincícios;

7. Uma linha de pesquisa para prosseguimento deste trabalho estaria vinculada à Epidemiologia em si, com a adoção de um subtipo viral existente em uma região especifica do Brasil e verificar o impacto na dinâmica do Sistema Imune dos pacientes infectados com tal subtipo do HIV-1. 


\section{Referência bibliográfica}

ABBAS, A K; LICHTMAN, A H; POBER, J S Imunologia Celular e Molecular. 4 edição, Ed. Revinter Ltda, 2003.

ANDERSON, R M; MAY, R M. The transmission dynamics of Human Immunodeficiency Virus (HIV). Philos Trans R Soc Lond B Biol Sci, v.321, n. 1207, p.565-607, 1998.

AQUARO, $\mathrm{S}$ et al. Macrophage and HIV infection: Therapeutical approach toward this strategic virus reservoir. Antiviral Res, n. 55, p. 209-25, 2002.

ASQUITH, B. et al. Inefficient cytotoxic T lymphocyte-mediated killing of HIV-1-infected cells in vivo. PLoS Biol, v.4, n.4, p.1-10, 2006.

BRAUER, F The Kermack-McKendrick epidemic model revisited. Math Biosci, v.198, n. 2, p. 119-31, 2005.

BURATTINI, M N et al. Modelling the dynamics of Leishmaniasis considering human, animal host and vector populations. Journal of Biological Systems, v. 6, n. 4, p. 337-56, 1998.

CALLARD, R E; YATES, A J. Immunology and Mathematics: crossing the divide. Immunology, v.115, n.1, p. 21-33, 2005.

CASTELlinO, F; GERMAIN, R N. Cooperation between CD4+ and CD8+ T cells: When, where, and how. Annual Reviews of Immunology, v, 24, n. 5, p. 519-40, 2006.

CHAUDHRY, M A S. et al. Empirical Models of the proliferative response of Cytokinedependent hematopoietic cell lines. Biotechnol Bioeng, v. 88, n. 3, p. 348-58, 2004.

CIUPE, M S et al. Estimating kinetics parameters from HIV primary infections data through the eyes of three different mathematical models. Math Biosci, v. 200, p. 1-27, 2006.

COLLMAN, R. G. et al. HIV and cells of Macrophage/dendritic lineage and others non-Tcell reservoirs: new answers yield new questions. J Leukoc Biol, v. 74,p. 631-4, 2003.

COUTINHO, F A B et al. Threshold conditions of the Non-autonomous epidemics system describing the population dynamics of Dengue. Bull Math Biol, v. 68, p. 2263-82, 2006.

CROWE, S; ZHU, T; MULLER, W A. The contribution of monocyte infection and trafficking to the viral persistence, and maintenance of the viral reservoir in HIV infection. J Leukoc Biol, v. 74, p. 635-41, 2003.

CULSHAW, R V; RUAN, S G; WEBB, G The mathematical model of cell-to-cell spread of HIV-1 that includes a time delay. J Math Biol, v. 46, n. 5, p. 425-44, 2003. 
De BOER; HOGEWEG, P. Interactions between macrophages and T-lymphocytes: Tumor sneaking through intrinsic to helper T cell Dynamics. J Theor Biol, v. 120, p. 331-351, 1986.

De BOER et al.. Macrophage T lymphocyte interactions in the anti-tumor immune response: A Mathematical Model. The Journal of Immunology, v. 134, n. 4, p. 2748-58, 1985.

De PILLIS, L G; RADUNSKAYA, A E; WISEMAN, C L. A validated mathematical model of cell-mediated immune response to tumor growth. Cancer Res, v. 65, n, 17, p. 7950-8, 2005.

De PILLIS, LG; RADUNSKAYA, A E. A mathematical model of immune response to tumor invasion. Computational Fluid and Solid Mechanics, Second MIT Conference of Computational Fluid and Solid Mechanics, K J Bathe (editor); 2003.

De SOUZA, F M C; De MENDONÇA, R N Modeling the dynamics of HIV-1 and CD4 and CD8 lymphocytes. IEEE Eng Med Biol Mag, v. 18, n. 1, p. 21-4, 1999.

DIXIT, N M; PERELSON, A S. Complex patterns of viral load decay under antiretroviral therapy: influence of pharmacokinetics and intracellular delay. J Theor Biol, v. 226, p. 95-109, 2004.

DUTTON, R W; BRADLEY, L M; SWAIN, S L. T cell memory. Annual Reviews of Immunology, v. 16, p. 201-33, 1998.

ESSUNGER, P; PERELSON, A S. Modeling HIV infection of CD4+ T-cell subpopulation. $\boldsymbol{J}$ Theor Biol, v. 170, p. 367-91, 1994.

FAUCI, A S et al. Immunopathogenic mechanism of HIV infection. NIH Conference, v. 124, n. 7, p. 654-63, 1996.

FERGUNSON, N M et al. Antigen-driven CD4+ T cell and HIV-1 dynamics: residual viral replication and highly active antiretroviral therapy. Proc Natl Acad Sci U S A, v. 96, n. 26, p. $15167-72,1999$.

FRASER, C; FERGUSON, N M; ANDERSON, R M. Quantification of intrinsic residual viral replication in treated HIV-infected patients. Proc Natl Acad Sci U S A, v. 98, n. 26, p. 15167-72, 2001.

GEIJTENBEEK, T B H et al. DC-SIGN, a dendritic cell specific HIV-1 binding protein that enhances trans-infection of Tcells. Cell, v. 100, p. 587-97, 2000.

GORRY, P R et al. Pathogenesis of Macrophage tropic HIV-1. Curr HIV Res, v. 3, n. 1, p. 5360, 2005.

HAASE, A T. Population biology of HIV infection: Viral and CD4+ T cell demographic and dynamics in lymphatic tissues. Annual Reviews of Immunology, v. 17, p. 625-56, 1999. 
HERZ, A V M et al. Viral dynamics in vivo: Limitations on estimates of intracellular delay and virus decay. Proc Natl Acad Sci U S A, v. 93, p. 7247-51, 1996.

HLAVACEK, W S et al. Retention of antigen on follicular dendritic cells and B lymphocyte through complement-mediated multivalent ligand-receptor interactions: Theory and implications to HIV treatment. Math Biosci, v. 176, p. 185-202, 2002.

HLAVACEK, W S; STILIANAKIS, N I; PERELSON, A S. Influence of follicular dendritic cells on HIV dynamics. Philos Trans R Soc Lond B Biol Sci, v. 355, p. 1051-8, 2000.

HLAVACEK, W S; WOFSY, C; PERELSON, A S. Dissociation of HIV-1 from follicular dendritic cells during HAART: Mathematical analysis. Proc Natl Acad Sci U S A, v. 96, p. 14681-86, 1999.

HUANG, Y; ROSENKRANZ, S L; WU, H. Modeling HIV dynamics and antiviral response with consideration of time-varying drug exposures, adherence and phenotypes sensitive. Math Biosci, v. 184, p. 165-86, 2003.

HUANG, X C; VILLASANA, M. An extension of the Kermack-McKendrick model for AIDS epidemics. Journal of Franklin Institute: Engineering and Applied Mathematics, v. 342, n. 4, p. 341-51, 2005.

JANSSEN, C A; van BAARLE, D; MIEDEMA, F. HIV-specific CD4+ T cells and viremia: Who's in control? Trends Immunol, v. 27, n. 3, p. 119-24, 2006.

JONES, L E; PERELSON, A S. Opportunistic infection as a cause of transient viremia in chronically infected HIV patients under treatment with HAART. Bull Math Biol, v. 67, p. 1227$51,2005$.

KERMACK, W O; McKENDRICK, A G. Contributions to the mathematical-theory of Epidemics I. Bull Math Biol, v. 53, n. 1-2, p. 33-55, 1991

KNIGHT, S C; ELSLEY, W; WANG, H. Mechanisms of loss of functional dendritic cells in HIV infections. J Leukoc Biol, v. 62, p. 78-81, 1997.

KOESTLER, S A. IL-7R $\alpha$ expression on CD4+ T lymphocytes decreases with HIV disease progression and inversely correlates with immune activation. Eur J Immunol, v. 36, p. 336-44, 2006.

LEE, ChuHEE et al. Macrophage activation through CCR5- and CXCR4-mediated gp120elicited signaling pathway. J Leukoc Biol, v. 74, p. 676-82, 2003.

LOPEZ L F et al. Modeling the control strategies against dengue in Singapore. Epidemiology and Infections (in press). 
LOPEZ, L F et al. A schematic age-structured compartment model of the impact of antiretroviral therapy on HIV incidence and prevalence. Mathematics and Computers in Simulations, v. 71, p. 131-48, 2006.

LOPEZ, L F et al. Which phase of the natural history of HIV infection is more transmissible? Int J STD AIDS, v. 13, n. 6, p. 430-1, 2002.

MACHADO, P R et al. Mecanismos de Resposta Imune às Infecções. An Bras Dermatol, v.79, n. 6, p. 647-62, 2004.

MACDONALD, G. The analysis of equilibrium in Malaria, Trop Dis Bull, v. 49, p. 813-28, 1952.

MACEY, R; OSTER, G; ZAHNLEY T. Berkeley Madonna User's Guide. Version 8.0.1. Department of Molecular and Cellular Biology University of California, Berkeley, CA, USA. 2000 .

MAHLKNECHT, U.; HERBEIN, G. Macrophage and T-cell apoptosis in HIV infection: a leading hole for accessory cells? Trends Immunol, v. 22, n. 5, p. 256-60, 2001.

MARAÑON, C. et al. Dendritic cells cross-present HIV antigens from live as well as apoptotic infected CD4+ T lymphocytes. Proc Natl Acad Sci U S A, v. 101, n. 16, p. 6092-7, 2004.

MASSAD, E. et al. A mixed ectoparasit-microparasite model for bat-transmitted rabies. Theor Popul Biol, v.60, p. 265-79, 2001.

MASSAD, E et al. The basic reproduction ratio of HIV among intravenous drug users. Math Biosci, v.123, n.2, p. 22-47, 1994.

McCUNE, J M. The dynamics of CD4+ T-cell depletion on HIV disease. Nature, v. 410, n. 19, p. 974-79, 2001.

MITTLER, J E et al. Influence of delayed virus production on viral dynamics in he HIV-1 infected patients. Math Biosci, v. 152, p. 143-63, 1998.

MOHRI, $\mathrm{H}$ et al. Increased turnover of T lymphocyte in HIV-1 infections and its reduction by antiretroviral therapy. J Exp Med, v. 9, p. 1277-87, 2001.

MONTANER, SJ; PERNO, C F; CROWE, S. Macrophage infections by HIV-1: Focus on viral reservoirs and pathogenesis. J Leukoc Biol, v. 68, p. 301-2, 2000.

MOORE, H; GU, W. A mathematical model for treatment resistant mutations of HIV. Math Biosci Eng, v. 2, n. 2, p. 363-80, 2005.

MORIS, A et al. Dendritic cells and HIV-specific CD4+ Tcells: HIV antigen presentation, Tcell activation, and viral transfer. Blood, v. 108, n. 5, p. 1643-51, 2006. 
MÜLLER, V; VIGUERAS-GOMES, J F; BONHOEFFER, S. Decelerating decay of latently infected cells during prolonged therapy for human immunodeficiency vírus type 1 infection. $J$ Virol, v. 76, n. 17, p. 8963-5, 2002.

OLIVEROS, M P R; LOPEZ, L F. Prevalência e covariação de mutações relacionadas à resistência aos inibidores de protease do subtipo F do HIV-1. 2005. Dissertação (Mestrado em Fisiopatologia Experimental). Faculdade de Medicina, Universidade de São Paulo, São Paulo, 2005.

PERELSON, A S. Modelling viral and immune system dynamics. Nat Rev Immunol, v. 2, p. 28-36, 2002.

PERELSON, A S; NELSON, P W. Mathematical Analysis of HIV-1 dynamics in vivo. SIAM Reviews, v. 41, n. 1, p. 3-44, 1999.

PERNO, C F et al. Therapeutics strategies towards HIV-1 infections in Macrophages. Antiviral Res, v. 71, n. 2-3, p. 293-300, 2006.

POPE, M Early dendritic cell-driven events governing the mucosal transmission of HIV: Targets for vaccines and microbicides. IAVI Reports (Internactional Aids Vaccine Initiative), v. 8, n. 2, 2004.

PORCHERAY, F. et al. Macrophage activation and human immunodeficiency virus infection: HIV replication directs macrophages toward a pro-inflammatory phenotype while previous activation modulates macrophage susceptibility to infection and viral production. Virology, $\mathrm{n}$. 349, p. 112-20, 2006.

PORTELA, M C; LOTROWSKA, M. Assistência aos pacientes com HIV/AIDS no Brasil. Rev Saúde Pública, v. 40, suppl., p. 70-9, 2006.

ROSSI, M; LOPEZ, L F Mathematical Model of Immune System: Implication of Macrophages and Dendritic cells on HIV infection. In: $13^{\text {th }}$ International Congress of Immunology, 2007. Rio de Janeiro. Proceedings of the $13^{\text {th }}$ International Congress of Immunology. Bologna: Medimond SrI, 2007, p.45-8 (H821s5610).

ROUZINE, I M; SERGEEV, R A; GLUSHTSOV, A I. Two types of cytotoxic lymphocyte regulation explain kinetics of immune response to human immunodeficiency virus. Proc Natl Acad Sci U S A, v. 103, n. 3, p. 666-71, 2006.

ROUZINE, I M; MURALI-KRISHNA, K; AHMED, R. Generals die in friendly fire or modeling immune response to HIV. J Comput Appl Math, v. 184, p. 258-74, 2005.

SCHACKER, T. et al. Rapid accumulation of human immunodeficiency virus (HIV) in lymphatic tissue reservoirs during acute and early HIV infections: Implications for timing of antiretroviral therapy. J Infect Dis, v. 181, p. 354-7, 2000. 
SCHRIER, R D; McCUTCHAN, J A; WILEY, C A. Mechanism of Immune activation of human immunodeficiency virus in monocytes/macrophages. $J$ Virol, v. 67, n. 10, p. 5713-20, 1993.

SILICIANO, R F. Viral pathogenesis: HIV persistence and resistance in latent reservoirs. Clinical Care Options, 2006.

SMITH, P D. et al. Biological parameters of HIV-1 infections in primary intestinal lymphocytes and macrophages. J Leukoc Biol, v. 68, n. , p. 360-5, 2000.

STEBBING, J; BOWER, M Opossing rules of Dendritic Cells subsets in HIV infection. Blood, v. 108, n. 6, p. 1785-6, 2006.

SWINGLER, S. et al. HIV-1 Nef intersects the macrophage CD40L signaling pathway to promote resting-cell infection. Nature, v. 424, n. 10, p. 213-9, 2003.

UNANUE, E R; BENACERRAF U. Imunologia. $2^{\circ}$ edição. Editora Guanabara, 1984.

VAHAM, G. et al. Modeling HIV transfer between dendritic cells and Tcells: importance of HIV phenotype, dendritic cell Tcell contact and Tcell activation. AIDS, v. 14, p. 2299-311, 2000.

VERANI, A.; GRAS, G.; PANCINO, G. Macrophages and HIV-1: dangerous liaisons. Mol Immunol, v. 42, p. 195-212, 2005.

VEROTTA, D; SCHAEDELI, F. Non-linear dynamics models characterizing long-term virological data from AIDS clinical trials. Math Biosci, v. 176, p. 163-83, 2002.

VOET, D; VOET, J G. Bioquímica, 3 ed. J. Wiley\&Sons, New York, 2004.

WALKER, B D. Immune control and immune failure in HIV infection. Clinical Care Options, 2006.

WEI, J J; ZOU, X F Bifurcation analysis of a population model and epidemic model with delay. J Comput Appl Math, v. 197, p. 169-87, 2006.

WICK, W D. et al. How many Human Immunodeficiency virus type 1-infected target cells can a cytotoxic T-lymphocyte kill? J Virol, v. 79, n. 21, p. 13579-86, 2005.

WU, L; KEWALRAMANI, V N. Dendritic-cell interactions with HIV: infection and viral dissemination. Nat Rev Immunol, v. 6, p. 859-68, 2006. 
Apêndice A 
Quadro A.1 - Principais antígenos e suas respectivas células-fonte, com descrições dos campos de atuação no Sistema Imune.

\begin{tabular}{|c|c|c|}
\hline ANTÍ GENO & CÉLULAS & FUNÇÕES \\
\hline CD1 a,b,c,d & $\begin{array}{l}\text { Timócitos } \\
\text { Células Dendríticas } \\
\text { Linfócito B (CD1C) } \\
\text { Células do Epitélio Intestinal } \\
\text { (CD1d) }\end{array}$ & $\begin{array}{l}\text { Molécula semelhante } \\
\text { ao MHC classe } 1 \text {, } \\
\text { especializada na } \\
\text { apresentação de } \\
\text { Antígenos }\end{array}$ \\
\hline CD4 & $\begin{array}{l}\text { Sub Grupo de Timócitos } \\
\text { Linfócito T auxiliar e inflamatório } \\
\text { Monócitos e Macrófagos }\end{array}$ & $\begin{array}{l}\text { Co-receptor de } \\
\text { moléculas de MHC de } \\
\text { classe 2. Receptor } \\
\text { para HIV-1 e HIV-2 }\end{array}$ \\
\hline CD8 & $\begin{array}{l}\text { Sub-grupo de Timócitos } \\
\text { Linfócitos T Citotóxicos }\end{array}$ & $\begin{array}{l}\text { Co-receptor para MHC } \\
\text { de classe } 1\end{array}$ \\
\hline CD9 & $\begin{array}{l}\text { Linfócito Pré-B } \\
\text { Eosinófilos } \\
\text { Basófilos } \\
\text { Monócitos } \\
\end{array}$ & $\begin{array}{l}\text { Possível função na } \\
\text { agregação e ativação } \\
\text { das plaquetas }\end{array}$ \\
\hline CD33 & \begin{tabular}{|l|} 
Células Mielóides \\
Progenitoras \\
Monócitos \\
\end{tabular} & Desconhecidas \\
\hline CD34 & $\begin{array}{l}\text { Precursores Hematopoiéticos ou } \\
\text { Células-Tronco Pluripotencial }\end{array}$ & Ligante para CD62L \\
\hline CD62L & Leucócitos ativados & $\begin{array}{l}\text { Receptor de } \\
\text { transfenina }\end{array}$ \\
\hline CD166 & $\begin{array}{l}\text { Atividade Leucocitária na adesão } \\
\text { de moléculas }\end{array}$ & $\begin{array}{l}\text { Ativação de Linfócito T } \\
\text { e B } \\
\text { Eosinófilos, Fibroblasto } \\
\text { Células Tímicas } \\
\text { Endoteliais e } \\
\text { Queratinócitos }\end{array}$ \\
\hline
\end{tabular}

Fonte: NAOUM, P C Avanços tecnológicos em hematologia laboratorial. Revista Brasileira de Hematologia e Hemoterapia, v. 23, n. 2, p. 15-23, 2001. 
Quadro A.2 - Principais Interleucinas e suas fontes celulares de síntese e de ação.

\begin{tabular}{|c|c|c|}
\hline INTERLEUCINA & SÍNTESE & AÇÃO \\
\hline $\begin{array}{l}\mathrm{IL}-1 \alpha \\
\mathrm{IL}-1 \beta\end{array}$ & Macrófagos, Célula Epitelial & $\begin{array}{l}\text { Ativação do Linfócito T, células } \\
\text { tronco e Macrófagos. Febre }\end{array}$ \\
\hline IL -2 & Linfócito T & $\begin{array}{l}\text { Proliferação e ativação e } \\
\text { Linfócito T, CD4, CD6, e NL }\end{array}$ \\
\hline$I L-3$ & $\begin{array}{l}\text { Linfócito T, Célula tímica } \\
\text { epitelial }\end{array}$ & Início da Hematopoiese \\
\hline$I L-4$ & Linfócito T e Mastócito & $\begin{array}{l}\text { Ativação de Linfócito B. } \\
\text { Diferenciação das APC. }\end{array}$ \\
\hline$I L-5$ & Linfócito T e Mastócito & $\begin{array}{l}\text { Crescimento e diferenciação de } \\
\text { eosinófilos }\end{array}$ \\
\hline$I L-6$ & Linfócito T e Mastócito & $\begin{array}{l}\text { Crescimento e diferenciação de } \\
\text { linfócitos T e B. Produção de } \\
\text { proteínas de fase aguda. } \\
\text { Ativação das células-tronco. }\end{array}$ \\
\hline $\mathrm{IL}-7$ & Estroma da medula óssea & $\begin{array}{l}\text { Maturação de Linfócitos Pré-B e } \\
\text { Pré-T. }\end{array}$ \\
\hline $\mathrm{IL}-8$ & Macrófago & $\begin{array}{l}\text { Quimiostáticos para neutrófilos } \\
\text { e Linfócito T }\end{array}$ \\
\hline IL -9 & Linfócito T & Ativação dos mastócitos \\
\hline $\mathrm{IL}-10$ & $\begin{array}{l}\text { Linfócito T, Macrófago, Vírus } \\
\text { Epstein-Barr }\end{array}$ & $\begin{array}{l}\text { Supressor das funções dos } \\
\text { Macrófagos. Ativação de } \\
\text { Linfócito B }\end{array}$ \\
\hline IL - 11 & $\begin{array}{l}\text { Fibroblasto do Estroma } \\
\text { Medular }\end{array}$ & $\begin{array}{l}\text { Sinergia com IL - } 3 \text { e IL - } 4 \text { na } \\
\text { hematopoiese }\end{array}$ \\
\hline $\mathrm{IL}-12$ & Linfócito B e Macrófago & $\begin{array}{l}\text { Ativas as células NK e induz } \\
\text { diferenciação da célula TCD } 4^{+} \\
\text {em célula T helper type } 1\end{array}$ \\
\hline IL -13 & Linfócito $\mathrm{T}$. & $\begin{array}{l}\text { Crescimento e diferenciação de } \\
\text { Linfócito B e inibe ação de } \\
\text { Macrófagos }\end{array}$ \\
\hline $\mathrm{IL}-14$ & $\begin{array}{l}\text { Linfócito T } \\
\text { Alguns Linfócitos B. }\end{array}$ & $\begin{array}{l}\text { Fator de crescimento para } \\
\text { células B. I nibe a síntese de Ig. }\end{array}$ \\
\hline $\mathrm{IL}-15$ & Linfócito T & $\begin{array}{l}\text { Ativa célula NK, células TCD8 }{ }^{+}, \\
C D 4^{+} \text {. Linfócito B. Macrófagos e } \\
\text { células T intestinais } \alpha \text { e } \beta \text {. }\end{array}$ \\
\hline
\end{tabular}

Fonte: NAOUM, P C Avanços tecnológicos em hematologia laboratorial. Revista Brasileira de Hematologia e Hemoterapia, v. 23, n. 2, p. 15-23, 2001. 
Quadro A.3 - Denominações dos "Cluster of Differentation" e as principais subpopulações onde são encontrados.

\begin{tabular}{|c|c|}
\hline CD & SUBPOPULAÇÃO DE CÉLULAS I DENTI FI CADAS \\
\hline \multicolumn{2}{|r|}{ LINFÓCITO B } \\
\hline CD 10 & Pré-B; Estágio 1 dos Timócitos \\
\hline CD 19 & Pré-B; Linf \\
\hline CD 20 & Maioria dos Linfócitos B \\
\hline CD 21 & $\begin{array}{l}\text { Maioria dos Linfócitos B; do sangue; zona do manto e } \\
\text { folículo primário }\end{array}$ \\
\hline CD 22 & Maioria dos Linfócitos B; \\
\hline CD 24 & Ativação de Antígenos de Linfócitos B \\
\hline CD 38 & Linfócitos B \\
\hline CD 40 & Linfócitos B \\
\hline CD 72 & Linfócitos Pan-B \\
\hline CD 73 & Linfócitos B e sub grupos de Células T \\
\hline CD 74 & Linfócitos B e Magrófagos \\
\hline CDw 75 & Linfócitos B maduros e sub grupos de Células T \\
\hline CD 76 & Linfócitos B maduros, sub grupos de Células T e PMNs \\
\hline CDw 78 & Linfócitos Pan-B; Macrófagos \\
\hline \multicolumn{2}{|r|}{ LINFÓCITO T } \\
\hline CD 1 & Linfócitos T, Células de Langerhans \\
\hline CD 2R & Linfócitos $\mathrm{T}$ ativados \\
\hline CD 4 & Linfócitos T ( auxiliar/ indutor) \\
\hline $\mathrm{CD} 7$ & Linfócitos T e Timócitos \\
\hline CD 8 & Linfócitos T ( Citotóxico e supressor) \\
\hline CD 27 & Linfócitos T e Plasmócitos \\
\hline CD 28 & Linfócitos T Citotóxicos - CD8 ${ }^{+}$ \\
\hline $\mathrm{CD} 34$ & $\begin{array}{l}\text { Células progenitoras Linfóides, Centro Germinal de } \\
\text { Linfócitos B e Plasmócitos, Linfócitos T proliferantes. }\end{array}$ \\
\hline CD 45 RA & Linfócitos B, T e NK; Monócitos \\
\hline $\mathrm{CD} 45 \mathrm{RO}$ & Linfócitos T de memória, células Mielóides \\
\hline \multicolumn{2}{|r|}{ LINFÓCITO Natural Killer (NK) } \\
\hline $\mathrm{CD} 2$ & Linfócito T e maioria de NK \\
\hline CD 3 & Linfócitos $\mathrm{T}$ ativados \\
\hline $\mathrm{CD} 7$ & Maioria de Linfócitos T e Timócitos \\
\hline CD 11b & Monócitos e Linfócitos T \\
\hline CD 16 & Linfócitos NK, alguns Linfócitos T e Monócitos \\
\hline CD 56 & Linfócitos NK, alguns Linfócitos T \\
\hline CD 57 & Linfócitos NK, alguns Linfócitos T \\
\hline
\end{tabular}


Apêndice B 
Anexo I 


\begin{tabular}{|c|c|c|c|c|c|c|c|c|c|}
\hline & $m_{1}$ & 0 & 0 & 0 & 0 & 0 & 0 & 0 & $\left.f^{\prime}\left(v^{n}\right)\right]$ \\
\hline 慈, & $\beta_{1} f\left(v^{n}\right)$ & $m f_{1}$ & 0 & 0 & $-\beta_{m f} M f i$ & 0 & 0 & $-\psi_{1} M f i$ & $+f^{\prime}\left(v^{n}\right)$ \\
\hline 豆 & 0 & 0 & $D C_{1}$ & 0 & 0 & 0 & 0 & 0 & $f^{\prime}(v)$ \\
\hline $\begin{array}{ll}0 & 0 \\
0 & :-1\end{array}$ & 0 & 0 & $K_{1} f(v)$ & $D C_{2}$ & $-\beta_{d c} m D C$ & 0 & 0 & 0 & $-f^{\prime}(v)$ \\
\hline$\ddot{3}$ & 0 & a1 & 0 & $a 2$ & $a 3$ & 0 & 0 & 0 & 0 \\
\hline 禹善. & 0 & a4 & 0 & a5 & a6 & $-\left(\mu+\alpha^{*}\right)-\psi_{3} C T L$ & 0,005 & $-\psi_{3} I$ & 0 \\
\hline 急: & 0 & a7 & 0 & a8 & a9 & 0 & $-\left(\mu+\alpha_{\text {lat }}^{*}\right)-0,005$ & 0 & 0 \\
\hline ¿. & 0 & $\left(\psi_{1}^{c t l}-\xi^{\prime}\right) C T L$ & 0 & $\left(\psi_{2}^{c t l}-\phi^{\prime}\right) C T L$ & 0 & $\psi_{3}^{c c t} C T L$ & 0 & a10 & 0 \\
\hline 范. & $-\sigma f\left(v^{n}\right)$ & $Q_{3}$ & $-K_{2} v$ & 0 & 0 & $Q_{1}\left(\mu+\alpha^{*}\right)$ & $Q_{2}\left(\mu+\alpha_{\text {lat }}^{*}\right)$ & 0 & a11 \\
\hline 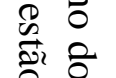 & & & $\mathrm{a} 4=z \mathrm{~B} \xi$ & $\Gamma 4(t-\tau) e^{-\left(\mu+\alpha^{*}\right) \tau}$. & $e^{-\lambda \tau}$ & $m_{1}=$ & $=l_{1}-\beta_{1} f\left(v^{n}\right)-\mu_{m}$ & & \\
\hline 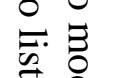 & & & $\mathrm{a} 5=z \mathrm{~B} \phi T$ & $4(t-\tau) e^{-\left(\mu+\alpha^{*}\right) \tau} \cdot e^{-\lambda}$ & & $m f_{1}=$ & $-\left(\mu_{f}+\alpha^{\prime}\right)-\beta_{m f} T 4-\psi_{1} C$ & $C T L$ & \\
\hline 華莡 & & & $\mathrm{a} 6=z \mathrm{~B}[\xi$. & $M f i(t-\tau)+\phi m D C(t$ & $-\tau)] e^{-\left(\mu+\alpha^{*}\right) \tau} \cdot e$ & $D C_{1}=$ & $=l_{2}-K_{1} f(v)-\mu_{i d}$ & & \\
\hline $\begin{array}{l}\infty \\
0 \\
\infty\end{array}$ & & & $\mathrm{a} 7=(1-z) \mathrm{E}$ & $\xi T 4\left(t-\tau_{\text {lat }}\right) e^{-(\mu+\alpha)}$ & lat) $\tau_{\text {lat }} \cdot e^{-\lambda \tau_{\text {lat }}}$ & $D C_{2}=$ & $=-\mu_{d c}-\beta_{d c} T 4-\psi_{2} C T L$ & & \\
\hline$\stackrel{0}{\Xi}$ & & & $\mathrm{a} 8=(1-z) \mathrm{F}$ & $\phi T 4\left(t-\tau_{l a t}\right) e^{-(\mu+\alpha)}$ & lat) Ilat $\cdot e^{-\lambda \tau \text { lat }}$ & $\mathrm{a} 1=\beta$ & $\beta_{m f} T 4-\mathrm{B} \xi T 4$ & & \\
\hline 背. & & & $\mathrm{a} 9=(1-z) \mathrm{E}$ & {$\left[\xi . M f i\left(t-\tau_{\text {lat }}\right)+\phi n\right.$} & $\left.n D C\left(t-\tau_{\text {lat }}\right)\right] e^{-}$ & $\left(\mu+\alpha+\alpha_{\text {lat }}^{*}\right) \eta_{\text {lat }} \cdot e^{-\lambda \tau \text { lat }}$ a2 $=\rho$ & $\beta_{d c} T 4-\mathrm{B} \phi T 4$ & & \\
\hline$\stackrel{0}{0}$ & & & $\mathrm{a} 10=\left(\psi_{1}^{\text {ct }}\right.$ & $\left.-\xi^{\prime}\right) M f i+\left(\psi_{2}^{c t l}-\phi^{\prime}\right) r$ & $n D C+\psi_{3}^{c t l} I-\mu$ & $\mathrm{a} 3=($ & $\left.\beta_{d c} m D C+\beta_{m f} M f\right) T 4-$ & $-\mathrm{B}(\xi M f$ & $\phi m D C)-\mu$ \\
\hline
\end{tabular}

